University of Louisville

ThinkIR: The University of Louisville's Institutional Repository

Electronic Theses and Dissertations

$5-2018$

\title{
A study of GPR3, GPR6, of GPR12 as novel molecular targets for cannabidiol.
}

Alyssa S. Laun

University of Louisville

Follow this and additional works at: https://ir.library.louisville.edu/etd

Part of the Medicine and Health Sciences Commons

\section{Recommended Citation}

Laun, Alyssa S., "A study of GPR3, GPR6, of GPR12 as novel molecular targets for cannabidiol." (2018). Electronic Theses and Dissertations. Paper 2945.

https://doi.org/10.18297/etd/2945

This Master's Thesis is brought to you for free and open access by ThinkIR: The University of Louisville's Institutional Repository. It has been accepted for inclusion in Electronic Theses and Dissertations by an authorized administrator of ThinkIR: The University of Louisville's Institutional Repository. This title appears here courtesy of the author, who has retained all other copyrights. For more information, please contact thinkir@louisville.edu. 


\title{
A STUDY OF GPR3, GPR6, AND GPR12 AS NOVEL MOLECULAR TARGETS FOR CANNABIDIOL
}

By

\author{
Alyssa S. Laun \\ B.S., University of Louisville, Louisville, KY; 2014 \\ A Thesis \\ Submitted to the Faculty of the \\ School of Medicine of the University of Louisville \\ in Partial Fulfillment of the Requirements \\ for the Degree of \\ Masters of Science in Pharmacology and Toxicology \\ Department of Pharmacology and Toxicology \\ School of Medicine \\ University of Louisville, Louisville KY
}

May 2018 



\title{
A STUDY OF GPR3, GPR6, AND GPR12 AS NOVEL MOLECULAR TARGETS FOR CANNABIDIOL
}

$$
\text { By }
$$

\author{
Alyssa S. Laun \\ B.S., University of Louisville, Louisville, KY; 2014 \\ A Thesis Approved on
}

April 20, 2018

by the following Thesis Committee:

Zhao-Hui Song, Ph.D.

Brian Ceresa, Ph.D.

David Hein, Ph.D.

Jonathan Freedman, Ph.D.

David Magnuson, Ph.D. 


\section{DEDICATION}

This thesis is dedicated to my girls

\section{Marlee Jade Aebersold and Charlotte Rea Aebersold:}

may this document forever serve to show them

that they, too, can achieve their dreams and hearts' desire. 


\section{ACKNOWLEDGMENTS}

I would like to acknowledge the late Dr. Steve Myers, who was one of my main advocates in pursuing further education. His words of advice and wisdom still influence my decisions today. I would also like to extend a thank you to my family, whose support and help have made attaining this degree possible. I must acknowledge my fiancé Tommy Aebersold who has given me unending support and understanding through the entire process.

I am grateful also for my mentor Dr. Zhao-Hui Song for his commitment and dedication to my academic success. I must also thank my committee members, Dr. David Hein, Dr. Brian Ceresa, Dr. Jonathan Freedman, and Dr. David Magnuson for their input to improve my thesis and overall project. Thank you to the department of Pharmacology and Toxicology, for believing in me and providing me with this platform to truly express myself academically and professionally. 


\begin{abstract}
A STUDY OF GPR3, GPR6, AND GPR12 AS NOVEL MOLECULAR TARGETS FOR CANNABIDIOL
\end{abstract}

Alyssa S. Laun

April 20, 2018

The G protein-coupled receptors 3, 6, and 12 (GPR3, GPR6, and GPR12) comprise a family of closely related orphan receptors with no confirmed endogenous ligands. These receptors are constitutively active, capable of signaling through $\mathrm{G}$ protein and non-G protein mediated mechanisms. These orphan receptors have previously been reported to play important roles in many normal physiological functions and to be involved in a variety of pathological conditions. Although they are orphans, GPR3, GPR6, and GPR12 are phylogenetically most closely related to the cannabinoid receptors. Using $\beta$-arrestin2 recruitment and cAMP accumulation assays, we have recently found that the nonpsychoactive phytocannabinoid cannabidiol (CBD) is an inverse agonist for GPR3, GPR6, and GPR12. This discovery highlights these orphan receptors as potential new molecular targets for $\mathrm{CBD}$, provides novel mechanisms of action, and suggests new therapeutic uses of CBD for illnesses such as Alzheimer's disease, Parkinson's disease, cancer, and infertility. Furthermore, identification of $\mathrm{CBD}$ as a new inverse agonist for GPR3, GPR6, and GPR12 provides the initial chemical scaffolds upon which potent and efficacious agents acting on these receptors can be developed, with the goal of 
developing chemical tools for studying these orphan receptors and ultimately new therapeutic agents. 


\section{TABLE OF CONTENTS}

\begin{tabular}{|c|c|}
\hline & PAGE \\
\hline $\begin{array}{l}\text { DEDICAIIUN ............. } \\
\text { ACKNOWLEDTS }\end{array}$ & $\cdots 111$ \\
\hline ABSTRACT & ..v \\
\hline
\end{tabular}

CHAPTER I: GPR3, GPR6, AND GPR12 INTRODUCTION .....................1
A. Introduction 1
B. Chromosomal Localization/ Distribution............................2

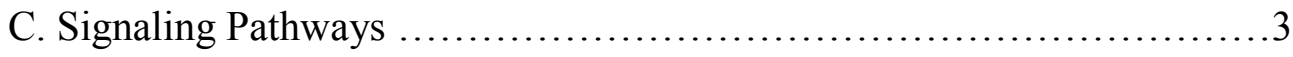

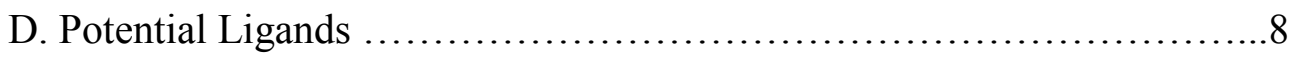

CHAPTER II: GPR3, GPR6, AND GPR12 PHYSIOLOGICAL IMPORTANCE ...10
A. GPR3 10
B. GPR6 17
C. GPR12 19

CHAPTER III: GPR3 AND GPR6, NOVEL MOLECULAR TARGETS FOR

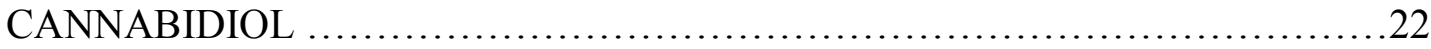
A. Introduction .22

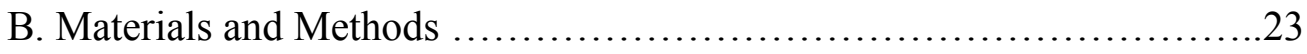

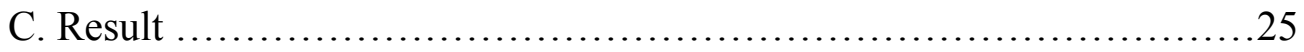

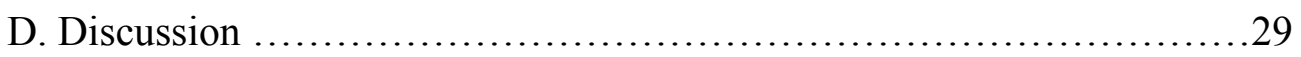

CHAPTER IV: FURTHER STUDY OF CBD …..............................32

A. Structure activity relationship study of CBD .........................32 
B. Molecular scaffold for future development of potent ligands

CHAPTER V: FUTURE STUDY OF CBD AND CONCLUDING REMARKS ...36

A. Potential Significance and Implications of CBD ....................36

B. Overall Impact and Concluding Remarks........................... 40

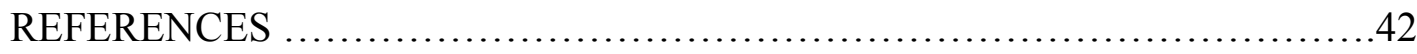

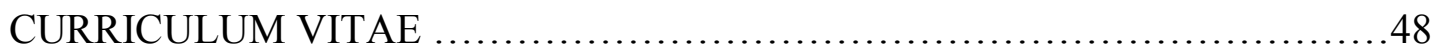




\title{
CHAPTER I
}

\section{GPR3, GPR6, AND GPR12 INTRODUCTION}

\begin{abstract}
A. Introduction
The G protein-coupled receptors 3, 6, and 12 (GPR3, GPR6, and GPR12) comprise a family of closely related receptors. These three receptors share roughly $60 \%$ amino acid identity. ${ }^{1}$ They are also phylogenetically related to the spingosine-1-phosphate (S1P) receptor, lysophosphatidic acid (LPA) receptor, melanocortin receptor, and cannabinoid receptors. $^{2,3}$ Despite being related, the similarity of GPR3, GPR6, and GPR12 to other receptor groups is not enough to suggest a common ligand. Since GPR3, GPR6, and GPR12 have no confirmed endogenous ligands, they are still classified as orphan receptors. $^{4}$

Recently, we have identified orphan receptors GPR3, GPR6, and GPR12 as novel targets for the phytocannabinoid cannabidiol (CBD). ${ }^{5-7}$ In this review, we will first survey the current literature detailing the molecular and functional aspects of GPR3, GPR6, and GPR12; this will be followed by a description of our recent discoveries involving CBD as a novel inverse agonist for these three orphan receptors. We will conclude by providing implications of our findings with regards to the mechanism of actions and the potential therapeutic uses of CBD.
\end{abstract}

\section{B. Cloning/ Chromosomal Localization/ Distribution}


GPR3: GPR3 was first cloned from a mouse cDNA library in $1993^{8}$, before being cloned from human genomic libraries by several independent groups. ${ }^{1,9-11}$ Recently, it was also cloned from porcine cDNA library. ${ }^{12}$ Marchese et al. ${ }^{9}$ mapped GPR3 to chromosome 1p35-1p36.1. Both Song et al. ${ }^{1}$ and Iismaa et al. ${ }^{10}$ mapped this receptor to 1p34.3-p36.1.

GPR3 mRNA is broadly expressed in neurons in the brain regions, including the cortex, thalamus, hypothalamus, amygdala, hippocampus, pituitary and cerebellum. ${ }^{10-13}$ Notably, the GPR3 protein is overexpressed in neurons in postmortem brain tissue sections of Alzheimer's disease afflicted individuals. ${ }^{14}$ GPR3 mRNA is also expressed in the eyes, lungs, kidneys, liver, testes, and ovaries, among other tissues. ${ }^{10-13}$

GPR6: GPR6 was first cloned from a rat cDNA library in 1994 and named rCNL3. ${ }^{15}$ This was followed by its cloning from human genomic DNA in $1995 .{ }^{1,16}$ Song et al. ${ }^{1}$ localized GPR6 to chromosomal region 6q21, and Heiber et al. ${ }^{16}$ specified that its chromosomal localization is $6 \mathrm{q} 21-22.1$. GPR6 mRNA is predominantly expressed in neurons in the brain, particularly the striatum (caudate, putamen, nucleus accumbens, and olfactory tubercle). It is also located in the frontal cortex, retrosplenial cortex, hippocampus, amygdala and hypothalamus to a lesser extent. ${ }^{15,16}$

Peripheral expression of GPR6 is apparently low. Song et al. ${ }^{15}$ did not detect GPR6 mRNA in the heart, spleen, lung, liver, muscle, kidney, or testis in rats. However, Ignatov et al. ${ }^{17}$ were able to detect relatively low levels of GPR6 mRNA in testis and skeletal muscle in mice.

GPR12: GPR12 was originally isolated from a rat cDNA library in 1991 and named R334. ${ }^{18}$ Two years later, it was isolated from a mouse cDNA library and re-named 
GPCR01. ${ }^{8}$ The receptor was ultimately cloned from a human genomic DNA library in 1995 and mapped to chromosomal region $13 \mathrm{q} 12^{1}$

GPR12 mRNA was originally identified in the pituitary. ${ }^{18}$ In the brain, the transcript is expressed in neurons in frontal cortex, piriform cortex, thalamus, hypothalamus, hippocampus, amygdala, and olfactory bulb. Peripherally, GPR12 mRNA is found in testis and oocytes. ${ }^{8,13,18,19}$

\section{Signaling Pathways}

Numerous groups have studied GPR3, GPR6, and GPR12 either individually or concurrently in regard to their coupling possibilities (Table 1). In this section, we have divided subsections by cell signaling pathway, rather than receptors in order to reflect cohesiveness.

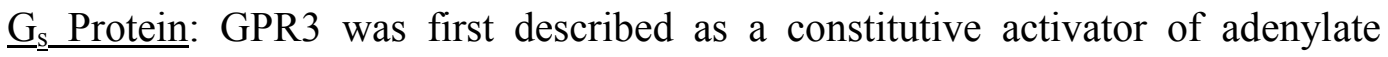
cyclase by Eggerickx et al in $1995 .{ }^{11}$ They found that GPR3 activates adenylate cyclase as measured by cAMP accumulation; the level of activation was comparable to other ligand activated, $\mathrm{G}_{\mathrm{s}}$-coupled receptors. They further determined that this result was not due to a mutation of the receptor, and was independent of species or cell type. ${ }^{11}$ The group hypothesized that this constitutive activity could be due to stimulation by a ubiquitous ligand that may be free, membrane-bound, or membrane-derived. Alternatively, they propose that this could also be due to basal $G_{s}$ coupling. Various groups have since supported this initial finding of GPR3 constitutive activation, and have gone on to show similar $\mathrm{G}_{\mathrm{s}}$ activity in GPR6 and GPR12. ${ }^{20-22}$

Notably in 2002, Uhlenbrock, Gassenhuber, and Kostenis ${ }^{20}$ showed that GPR3, GPR6, and GPR12 constitutive activity occurred in the presence of medium prepared 
with serum. When the cells were serum starved, the constitutive activity was reduced, potentially suggesting the involvement of an endogenous ligand.

Bresnick et al. ${ }^{21}$ sought to identify the signal transduction pathways used by various orphan GPCRs, including GPR3 and GPR12. They used cAMP response element (CRE)- $\beta$-lactamase as a cAMP reporter to study orphan receptors transfected into HEK293 cells. The results showed that both GPR3 and GPR12 activated a $\mathrm{G}_{\mathrm{s}}$ pathway since an increase of $\beta$-lactamase activity was observed after transfection with the respective receptor. GPR6 was not tested by this lab.

Martin, Steurer, and Aronstam ${ }^{22}$ studied GPR3, GPR6, and GPR12 concurrently in 2015 and provided further evidence of constitutive activity at these receptors. Using Chinese hamster ovary $(\mathrm{CHO})$ cells co-transfected with a CRE luciferase reporter and one of the three orphan receptor genes, they observed that cAMP signaling was constitutively stimulated. For each receptor, the constitutive stimulation observed was reported as greater than $200 \%$ stimulation above the baseline, which was their defined cutoff for constitutive activity.

$\underline{G}_{i / 0}$ Protein: Some of the aforementioned groups studying the coupling to the $G_{s}$ protein also studied $G_{i}$ in parallel. Using HEK293 cells transfected with either GPR3, GPR6, or GPR12, Uhlenbrock, Gassenhuber, and Kostenis ${ }^{20}$ concluded that all three receptors were constitutively activating $G_{i}$ as well. They demonstrated that adenylate cyclase stimulation was enhanced following treatment with pertussis toxin. Furthermore, overexpression of $\mathrm{G}_{\mathrm{i}}$ reduced cAMP levels stimulated by GPR3, GPR6, and GPR12. Since the signaling was enhanced upon $G_{i}$ inhibition by pertussis and inhibited upon $G_{i}$ overexpression, the data suggests that the three receptors couple to $\mathrm{G}_{\mathrm{i} .}{ }^{20}$ 
Martin, Steurer, and Aronstam ${ }^{22}$ took a different approach to measuring $G_{i}$ activity. Cells were co-transfected with the GPR3/6/12 and the CRE-luciferase reporter. Forskolin stimulation maximally stimulates cAMP production such that $\mathrm{G}_{\mathrm{s}}$-mediated production is non-significant and any constitutive coupling to $G_{i}$ becomes apparent by inhibition of cAMP signaling. Constitutive inhibition of adenylate cyclase activity was defined as a $40 \%$ decrease below forskolin baseline. It is worth noting that while they showed GPR6 and GPR12 expression led to a decrease of CRE-luciferase reporter expression, they observed that GPR3 did not constitutively inhibit forskolin stimulated cAMP. These findings somewhat contradict the previously mentioned group ${ }^{20}$ that found GPR3 constitutively activated $\mathrm{G}_{\mathrm{i}}$.

Ignatov et al. ${ }^{17}$ also conducted studies using pertussis toxin to inhibit $\mathrm{G}_{\mathrm{i}}$, but focused specifically in GPR6. They observed a suppression of ligand-induced $\mathrm{Ca}^{2+}$ mobilization in $\mathrm{CHO}$ cells overexpressing GPR6 following treatment of pertussis toxin, which suggests the role of $\mathrm{G}_{\mathrm{i} / \mathrm{o}}$ in GPR6-mediated $\mathrm{Ca}^{2+}$ mobilization. In addition, Ignatov et al. ${ }^{19}$ suggested that GPR12 couples to $\mathrm{G}_{\mathrm{i} / \mathrm{o}}$, because ligand-induced GIRK currents were blocked by pertussis toxin in Xenopus oocytes.

Non-G Proteins: Tanaka et al. ${ }^{23}$ demonstrated that GPR3 acts through extracellular signal-regulated kinase 1/2 (ERK1/2) and protein kinase B (Akt) signaling to mediate anti-apoptotic effects. By downregulating GPR3 in cerebellar granule neurons, levels of ERK and Akt phosphorylation were reduced. This group also discovered that by adding a protein kinase A (PKA), ERK1/2, or phosphatidylinositol-3-kinase (PI3) inhibitor, the anti-apoptotic effect of GPR3 could be blocked. 
In contrast, Ignatov et al. ${ }^{17}$ showed that GPR6 inhibits apoptotic cell death through a mechanism that relies on activation of sphingosine kinase in addition to ERK1/2 phosphorylation. In PC12 cells, GPR12 activated the ERK1/2 signaling pathway and caused a consequential increase in expression of Bcl-2, Bcl-xl, and SYP ${ }^{24}$.

Lowther et al. ${ }^{25}$ showed that GPR3 signals at the level of plasma membrane, and undergoes desensitization and internalization through mechanisms involving GPCR regulated kinase 2 and $\beta$-arrestin2.

A group studying Alzheimer's disease determined that GPR3 expression modulates amyloid $\beta(\mathrm{A} \beta)$ production through $\beta$-arrestin2. ${ }^{26}$ Neither GPR6 nor GPR12 were included in this study. Overexpression of $\beta$-arrestin2 increased $A \beta$ production, whereas silencing decreased $A \beta$ production. GPR3 is critical for this process, as evidenced by the fact that elevation of $A \beta$ by overexpression of $\beta$-arrestin 2 only occured when GPR3 was also expressed. ${ }^{26}$

Nelson and Sheng ${ }^{27}$ studied the GPR3- $\beta$-arrestin2 interaction by mutating the receptor. Through truncation of the $\mathrm{C}$-terminal tail - the location at which $\beta$-arrestin2 interacts with GPR3 - A $\beta$ production and colocalization of GPR3 and amyloid precursor protein (APP) were decreased. It is clear from these results that $\beta$-arrestin2 is the key for the interaction between GPR3 and APP, which led to enhanced A $\beta$ production ${ }^{27}$.

Yin et al. ${ }^{28}$ used the $\beta$-arrestin2 PathHunter assay system to measure $\beta$-arrestin2 recruitment in HEK293 cells transiently transfected with GPR3, GPR6 and GPR12. However, they found no ligand-induced $\beta$-arrestin2 recruitment through these receptors when testing with any of the previously reported agonists for this receptor. 


\section{Table 1}

Signaling Pathways of GPR3, GPR6, and GPR12

\begin{tabular}{|c|c|c|c|}
\hline $\begin{array}{l}\text { Signaling } \\
\text { Pathway }\end{array}$ & GPR3 & GPR6 & GPR12 \\
\hline \multicolumn{4}{|l|}{ G protein } \\
\hline $\mathrm{G}_{\mathrm{s}}$ & $\begin{array}{l}\text { Constitutively active }{ }^{11,20-22} \\
\uparrow \text { AC activation } 11,20 \\
\uparrow \text { cAMP reporter }^{21,22}\end{array}$ & $\begin{array}{l}\text { Constitutively active } e^{20,22} \\
\uparrow \text { AC activation } \\
\uparrow \text { cAMP reporter }^{22}\end{array}$ & $\begin{array}{l}\text { Constitutively } \\
\text { active }^{20-22} \\
\uparrow \mathrm{AC} \\
\text { activation }^{20} \\
\uparrow \text { cAMP }^{21,22} \\
\text { reporter }^{21,22}\end{array}$ \\
\hline $\mathrm{G}_{\mathrm{i}}$ & $\begin{array}{l}\text { Constitutively active } \\
\text { PTX treatment } \uparrow A C \\
\text { activation }^{20} \\
G_{\alpha i} \text { overexpression } \downarrow^{20} \\
\text { cAMP } \\
\text { No effect on cAMP reporter } \\
\text { after forskolin stimulation }\end{array}$ & $\begin{array}{l}\text { Constitutively active } \\
\text { PTX treatment } \uparrow A C \\
\text { activation }^{20} \\
\mathrm{G}_{\alpha \mathrm{i}} \text { overexpression } \downarrow^{20} \\
\text { cAMP } \\
\text { PTX treatment } \downarrow \text { ligand } \\
\text { induced } \mathrm{Ca}^{2+} \\
\text { mobilization }^{17} \\
\downarrow \text { cAMP reporter after } \\
\text { forskolin stimulation }\end{array}$ & $\begin{array}{l}\text { Constitutively } \\
\text { active } 22 \\
\downarrow \text { cAMP } \\
\text { reporter after } \\
\text { forskolin } \\
\text { stimulation } \\
\text { PTX } \\
\text { treatment } \\
\downarrow \text { ligand } \\
\text { induced } \\
\text { GIRK } \\
\text { currents }{ }^{19}\end{array}$ \\
\hline \multicolumn{4}{|c|}{ Non- G protein } \\
\hline $\begin{array}{l}\text { ERK1/2 } \\
\text { pathway }\end{array}$ & $\begin{array}{l}\text { Signals via ERK1/2 and } \\
\mathrm{Akt}^{29}\end{array}$ & $\begin{array}{l}\text { Signals via ERK1/2 and } \\
\text { sphingosine kinase } \\
\text { phosphorylation }^{17}\end{array}$ & $\begin{array}{l}\text { Signals via } \\
\text { ERK } 1 / 2^{24}\end{array}$ \\
\hline$\beta$-arrestin 2 & $\begin{array}{l}\text { No ligand induced } \beta \text { - } \\
\text { arrestin } 2 \text { recruitment } \\
\text { Internalization and } \\
\text { desensitization using GRK2 } \\
\text { and } \beta \text {-arrestin } 2^{25} \\
\text { Modulation of } A \beta \\
\text { production via } \beta \text { - } \\
\text { arrestin } 2^{26,27}\end{array}$ & $\begin{array}{l}\text { No ligand induced } \beta \text { - } \\
\text { arrestin2 recruitment }\end{array}$ & $\begin{array}{l}\text { No ligand } \\
\text { induced } \beta \text { - } \\
\text { arrestin2 } \\
\text { recruitment }^{28}\end{array}$ \\
\hline
\end{tabular}

$\mathrm{AC}=$ adenylate cyclase; $\mathrm{PTX}=$ pertussis toxin; $\mathrm{cAMP}=$ cyclic adenosine monophosphate; ERK1/2 $=$ extracellular signal-regulated kinase $1 / 2 ; \mathrm{Akt}=$ protein kinase $\mathrm{B}$; GRK2= GPCR regulated kinase 2; GIRKcurrents $=\mathrm{G}$ protein-activated inwardly rectifying $\mathrm{K}^{+}$currents 


\section{Potential Ligands}

GPR3: Sphingosine 1-phosphate (S1P) and dihydrosphingosine 1-phosphate (DHS1P) were first demonstrated to be agonists of GPR3 by the lab of Uhlenbrock, Gassenhuber, and Kostenis ${ }^{20}$, as activation by these ligands increased cAMP concentration in GPR3-transfected cells. However, this claim has been challenged by several groups, who could not reproduce the results using these lysophospholipid ligands. ${ }^{14,28,30}$

Diphenyleneiodonium chloride (DPI) is another proposed agonist for GPR $3^{31}$. In HEK293 cells stably expressing GPR3, DPI stimulated numerous signaling pathways including $\mathrm{Ca}^{2+}$ mobilization, cAMP accumulation, $\beta$-arrestin2 recruitment, and receptor internalization. In comparison, the putative agonist S1P failed to induce either $\beta$-arrestin2 recruitment or cAMP accumulation in cells stably expressing GPR3.

In addition, an inverse agonist has also been identified for GPR3. ${ }^{32}$ AF64394 and its analogues were shown to reduce cAMP accumulation. AF64394, though, had the most pronounced effect out of the set of compounds tested, with a reported $\mathrm{pIC}_{50}$ of 7.3.

GPR6: Both Uhlenbrock, Gassenhuber, and Kostenis ${ }^{20}$ and Ignatov et al. ${ }^{17}$ identified S1P as a ligand for GPR6 using the calcium mobilization assays, which showed S1P-induced and GPR6-mediated intracellular calcium release.Conflictingly, Yin et al. ${ }^{28}$ did not detect any S1P-agonism activity for GPR6 when using the PathHunter $\beta$-arrestin2 assay, and thus concluded that GPR6 remains an orphan receptor.

GPR12: With the use of calcium mobilization assay, Uhlenbrock, Gassenhuber, and Kostenis ${ }^{20}$ proposed that S1P is a ligand for GPR12. More importantly, Ignatov et al. ${ }^{19}$ then showed that sphingosylphosphorylcholine (SPC) had higher affinity than S1P 
for GPR12. The same lab that refuted the notion that lysophospholipids are ligands for GPR3 and GPR6 likewise reported that GPR12 did not respond to either S1P or SPC in their $\beta$-arrestin 2 recruitment experiments. ${ }^{28}$

In addition to these studies on S1P and SPC, reports have also been published on several other potential and unique ligands for GPR12. Lin et al. ${ }^{33}$ studied a set of 15 different compounds isolated from endophytic Streptomyces sp. and found tyrosol to be the only ligand that promoted a significant increase in cAMP in both the CHO and HEK293 cells transfected with GPR12. In a separate study, the same laboratory isolated 4-(hydroxymethyl)-5-hydroxy-2H-pyran-2-one from the marine-derived fungus Aspergillus flavus, and found the compound concentration-dependently stimulates cAMP production in cells transfected with GPR $12 .{ }^{34}$ In a similar vein, Du et al. ${ }^{35}$ isolated and characterized various compounds from Penicillium citrinum, a volcanic ash- derived fungus, five of which induced cAMP production in CHO cells transfected with GPR12 at a concentration of $10 \mu \mathrm{M}$. 


\section{CHAPTER II}

\section{GPR3, GPR6, AND GPR12 PHYSIOLOGICAL IMPORTANCE}

\section{A. GPR3}

Neurite outgrowth/neuronal cell survival: Neurite is a general term for any projection off of a neuron, and include dendrites and axons. In 2007, Tanaka et al. ${ }^{29}$ showed that overexpression of the GPR3 receptor enhanced the neurite outgrowth of cerebellar granule neurons (Table2). In contrast, knockdown of GPR3 resulted in a reduction of neurite outgrowth. Interestingly, neurite outgrowth in receptor knockout mice could be rescued by either GPR3 or GPR12 expression. Additionally, they showed that GPR3 is endogenously enhanced in developing rat cerebellar granule neurons, which they suspect is important for development. ${ }^{29}$

Tanaka et al. $^{36}$ also demonstrated that endogenous GPR3 expression in rat cerebellar neurons was anti-proliferative because its knockdown via siRNA enhanced proliferation, whereas exogenous GPR3 expression partially antagonized proliferation. Exogenous GPR3 expression also correlated with an increase in p27/kip, which promotes mitotic exit and is another key regulator of proliferation in the developing cerebellum. In contrast, GPR3 knockdown decreased p27/kip expression. They further showed using cell cycle kinetic studies that GPR3 arrests the cell cycle at G1. ${ }^{36}$

This group continued their research on GPR3 in cerebellar granule neurons and found that GPR3 is also important for neuronal cell survival. The cerebellar granule 
neurons of GPR3 knockout mice exhibited lower survival in vitro compared to wild-type ${ }^{23}$. Brain sections from these mice also exhibited a higher number of caspase 3 positive neurons in the internal granular layer when compared with wild-type. In terms of signaling, knockdown of endogenous GPR3 inhibits ERK and Akt phosphorylation under normal culture conditions. Inhibition of PKA, MAPK, or PI3 kinase eliminated the GPR3-mediated anti-apoptotic effect. Lastly, GPR3 knockout mice exhibited a larger infarct compared to wild-type in a model of brain ischemia. ${ }^{23}$

Alzheimer's disease: Alzheimer's disease is a neurodegenerative disease with two distinct hallmarks: amyloid plaque formation and neurofibrillary tangles consisting of hyperphosphorylated tau. The first hallmark, amyloid plaques, are produced from accumulations of A $\beta$ proteins. Cleavage of the APP by $\gamma$ secretase generates A $\beta$. The major species of amyloid protein synthesized from this cleavage are $\mathrm{A} \beta 40$ and $\mathrm{A} \beta 42$, with $A \beta 42$ being the more fibrogenic species of the two. GPR3 has been identified as a mediator of $\mathrm{A} \beta$ production by two independent groups. ${ }^{14,26,27,37}$

Thathiah et al. ${ }^{14}$ demonstrated that GPR3 increases $\gamma$ secretase activity in vitro by co-transducing hippocampal neuronal cells with a direct substrate for $\gamma$ secretase that produces A $\beta$ (APP-C99) and GPR3. By immunoblotting cell membrane extracts from HEK293 cells transfected with GPR3, they have shown that GPR3 increases cell surface localization of $\gamma$ secretase subunits. In an Alzheimer's disease cell culture model, overexpression of GPR3 increased A $\beta$ secretion, while ablation of GPR3 using siRNA decreased the amount of $A \beta$ produced. Furthermore, they demonstrated that GPR3 is highly expressed in the normal human brain, specifically in areas implicated in 
Alzheimer's disease, and can then become overexpressed in the sporadic Alzheimer's disease brain.

Using co-immunoprecipitation methods, this same group later showed that $\beta$ arrestin 2 interacts with the Aph-1a subunit of the $\gamma$-secretase complex. ${ }^{26}$ In addition, they demonstrated that downregulation of $\beta$-arrestin2 by siRNA in HEK-APP695 cells, as well as $\beta$-arrestin2 knockout in mice, led to a reduction of accumulation of the APP Cterminal fragments $A \beta 40$ and $A \beta 42$. This outcome is similar to the result produced by an inhibitor of $\gamma$ secretase. Moreover, they demonstrated that $\beta$-arrestin2 expression was high in Alzheimer's disease patients' postmortem brain, and that overexpression of $\beta$ arrestin2 increased $A \beta$ generation.

The same group, Huang et al. ${ }^{37}$ later studied the importance of GPR3 in four different Alzhiemer's disease transgenic mouse models. In all four of the models used, GPR3 knockout reduced amyloid pathology and improved memory. They also showed improved memory in GPR3 knockout/AD model mice.

In 2013, Nelson and Sheng ${ }^{27}$ demonstrated that GPR3 is capable of complexing with APP, an interaction that is made possible by $\beta$-arrestin2. They observed that $\beta$ arrestin2 alone failed to increase A $\beta$ production in vitro in HEK293 cells transfected with APP. Only after additional transfection with GPR3 was there an increase in A $\beta$ production. $\beta$-arrestin2 is important nonetheless, as siRNA knockdown of $\beta$-arrestin2 lowered the A $\beta$ produced in GPR3 transfected cells. In addition, Nelson and Sheng ${ }^{27}$ showed that GPR3 co-localizes with endogenous APP in clusters, and that $\beta$-arrestin2 also partially co-localizes with GPR3 in mature rat hippocampal neurons. Furthermore, 
GPR3 increases the processing of APP, and the amount of A $\beta$ produced correlates with the amount of GPR3-APP binding.

Emotional behavior: GPR3 has been shown to modulate anxiety-related behavioral responses. Valverde et al. ${ }^{30}$ showed that GPR3 knockout mice displayed higher levels of avoidance to novel and unfamiliar environments compared to wild-type mice. This avoidance was associated with increased reactivity to stress in behavioral despair paradigms and to aggression in resident-intruder models. The authors determined that the reduced ability of GPR3 knockout mice to cope with stress was not due to changes in the hypothalamic-pituitary-adrenal axis since corticosterone levels were normal when exposed to unfamiliar environments. They did, however, observe changes in monoamine neurotransmission in the hippocampus, hypothalamus, and forebrain of GPR3 knockout mice.

Neuropathic pain: Ruiz-Medina, Ledent, and Valverde ${ }^{38}$ studied the involvement of GPR3 in neuropathic pain after a spinal cord injury in mice. GPR3 knockout mice demonstrated hyperalgesia compared to mice positive for the receptor. Knockout mice also had reduced morphine anti-nociception, highlighting the importance of GPR3 in relieving neuropathic pain. There were no differences, however, in mechanical allodynia; microglia and astrocyte activation in the ipsilateral dorsal horn was comparable in both phenotypes, and thus inflammatory response was unaltered by the presence or absence of GPR3.

Addiction: Tourino et al. $^{39}$ showed that GPR3 modulates the early phases of cocaine reinforcement. GPR3 knockout mice exhibited higher responses to reward from cocaine, self-administered more cocaine, and had increased locomotor activity compared 
to wild-type control mice. Taken together, the authors suggested that the enhanced responsiveness in the early phases of reinforcement implicate GPR3 in developing addiction.

Obesity: GPR3 is purported to be important for age-related obesity. ${ }^{40}$ Mice lacking GPR3 exhibited normal weights for the first 5 months, before subsequently gaining excess weight. Heterozygous and homozygous knockout mice gained significantly more weight than their age-matched wild-type GPR3 littermates. Furthermore, GPR3 knockout mice displayed increased fat droplet accumulation, higher triglyceride content in the liver, and higher concentrations of leptin, all of which correlates with the higher adiposity. GPR3 knockout mice also had lower energy expenditure and decreased core body temperature, as well as a decrease in several markers for thermogenesis. ${ }^{40}$

Oocyte maturation /ovarian aging and ovarian failure: Prior to ovulation, oocytes are arrested in prophase I of meiosis. During ovulation, upon release of luteinizing hormone (LH), oocytes resume meiosis and undergo maturation. High levels of cAMP stimulated by $\mathrm{G}_{\mathrm{s}}$ activation of adenylyl cyclase are required to maintain meiotic arrest, whereas LH stimulation and reduction in cAMP levels are required for meiotic resumption. ${ }^{41}$ GPR3 was first identified as pivotal for oocyte meiosis in 2004, when Mehlmann et al. ${ }^{42}$ found that GPR3, which is localized to the oocyte, maintains the prophase I arrest in mice. GPR3 knockout mice oocytes were able to resume meiosis within antral follicles. Since its discovery, many independent groups have confirmed the role of GPR3 in oocyte maturation in many species, including mice, rats, frogs, pigs and humans. $^{12,42-45}$ 
Ledent et al. ${ }^{46}$ compared young vs. aged GPR3 knockout mice to determine if age affected fertility when GPR3 is absent. Young GPR3 knockout mice were fertile, though they had progressively smaller litter sizes. In contrast, aged mice lacking the receptor suffered severe infertility as embryos did not develop and fragmented oocytes presented after superovulation. Ledent et al. $^{46}$ thus concluded that GPR3 protects and possibly rescues oocytes from aging. 
Table 2

\section{$\underline{\text { Functional Significance of GPR3 }}$}

\begin{tabular}{|c|c|c|}
\hline $\begin{array}{l}\text { Physiological/ } \\
\text { Pathological } \\
\text { Indications }\end{array}$ & Significant Findings & Source \\
\hline \multirow{3}{*}{$\begin{array}{l}\text { Neurite } \\
\text { outgrowth/ } \\
\text { neuronal } \\
\text { survival }\end{array}$} & $\begin{array}{l}\text { GPR3 overexpression enhances neurite outgrowth of } \\
\text { cerebellar granule neurons }\end{array}$ & Tanaka et al. $^{29}$ \\
\hline & $\begin{array}{l}\text { GRP3 suppresses proliferation of cerebellar granule } \\
\text { precursors and mediates terminal differentiation }\end{array}$ & Tanaka et al. \\
\hline & $\begin{array}{l}\text { GPR3 demonstrates anti-apoptotic effects and involvement } \\
\text { in neuronal cell survival }\end{array}$ & Tanaka et al. \\
\hline \multirow[t]{4}{*}{$\begin{array}{l}\text { Alzheimer's } \\
\text { disease }\end{array}$} & $\begin{array}{l}\text { GPR } 3 \text { enhances A } \beta \text { production in neurons via } \gamma \text { secretase } \\
\text { activity; Elevated GPR } 3 \text { expression is correlated with } \\
\text { Alzheimer's disease progression in human post-mortem } \\
\text { brain tissue }\end{array}$ & $\begin{array}{l}\text { Thathiah et al. } \\
14\end{array}$ \\
\hline & $\begin{array}{l}\text { Both GPR } 3 \text { and } \beta \text {-arrestin } 2 \text { participate in } A \beta \text { production } \\
\text { and gamma-secretase activity in Alzheimer's disease }\end{array}$ & $\begin{array}{l}\text { Thathiah et } \\
\text { al. }^{26}\end{array}$ \\
\hline & $\begin{array}{l}\text { GPR } 3 \text {-APP complexes, in the presence of } \beta \text { arrestin2, } \\
\text { increase A } \beta \text { production }\end{array}$ & $\begin{array}{l}\text { Nelson and } \\
\text { Sheng }^{27}\end{array}$ \\
\hline & $\begin{array}{l}\text { Deletion of GPR3 reduces amyloid pathology and } \\
\text { improved memory in Alzheimer's disease mouse models }\end{array}$ & Huang et al. ${ }^{37}$ \\
\hline $\begin{array}{l}\text { Emotional } \\
\text { behavior during } \\
\text { stress }\end{array}$ & $\begin{array}{l}\text { GPR3 deletion is linked to higher levels of avoidance, } \\
\text { stress and aggression in mouse models }\end{array}$ & $\begin{array}{l}\text { Valverde et } \\
\text { al. }^{30}\end{array}$ \\
\hline $\begin{array}{l}\text { Neuropathic } \\
\text { pain }\end{array}$ & $\begin{array}{l}\text { GPR } 3 \text { knockout mice demonstrated hyperalgesia and } \\
\text { reduced morphine antinociception in a mouse neuropathic } \\
\text { pain model }\end{array}$ & $\begin{array}{l}\text { Ruiz-Medina, } \\
\text { Ledent, and } \\
\text { Valverde }^{38}\end{array}$ \\
\hline Addiction & GPR3 modulates early phases of cocaine reinforcement & $\begin{array}{l}\text { Tourino et } \\
\text { al. }\end{array}$ \\
\hline Obesity & $\begin{array}{l}\text { GPR3 knock-out mice exhibit thermogenic dysfunction and } \\
\text { subsequent late-onset obesity phenotype }\end{array}$ & $\begin{array}{l}\text { Godlewski et } \\
\text { al. }^{40}\end{array}$ \\
\hline \multirow{2}{*}{$\begin{array}{l}\text { Oocyte } \\
\text { maturation/ } \\
\text { ovarian aging } \\
\text { and ovarian } \\
\text { failure }\end{array}$} & $\begin{array}{l}\text { GPR3 maintains meiotic arrest of prophase I in mouse } \\
\text { oocytes }\end{array}$ & $\begin{array}{l}\text { Mehlmann et } \\
\text { al. } 2\end{array}$ \\
\hline & $\begin{array}{l}\text { GPR3 knockout mice display incomplete meiotic pause and } \\
\text { premature ovarian aging }\end{array}$ & Ledent et al. $^{46}$ \\
\hline
\end{tabular}

GPR $3=\mathrm{G}$ protein-coupled receptor $3 ; \mathrm{A} \beta$ production $=$ Amyloid $\beta$ production; $\mathrm{APP}=$ amyloid precursor protein 


\section{B. GPR6}

Neurite outgrouth/neuronal cell survival: The dependence of neurite outgrowth on cAMP was demonstrated by Cai et al. ${ }^{47}$ (Table3). GPR6, like GPR3 and GPR12, increases neurite outgrowth when overexpressed in rat cerebellar granule neurons. ${ }^{29}$ These results strongly indicate that GPR6, as well as GPR3 and GPR12, are critical for neurite outgrowth due to their constitutive activity to produce cAMP.

Alzheimer's disease: Individuals with Alzheimer's disease have been found to produce $\mathrm{C} 1 \mathrm{q}$, a protein that binds amyloid $\beta$ plaques and aids in clearance of the plaques, while also promoting a damaging inflammatory response ${ }^{48}$. Benoit et al. ${ }^{49}$ found that through a C1q-mediated mechanism GPR6 is upregulated in Alzheimer's disease mouse models. They also showed that GPR6 is crucial for the C1q-mediated neuroprotection against amyloid- $\beta$-induced neurotoxicity in the mouse model. As such, GPR6 may play a key role for neuroprotection in individuals with Alzheimer's disease. ${ }^{49}$

Parkinson's disease: GPR6 also has implications for Parkinson's disease. GPR6 deficient mice have increased dopamine concentrations in striatal tissue, decreased cAMP concentration in intact mice striatum, and improved motor activity while decreasing abnormal movements in the mouse dyskinesia model of Parkinson's disease. ${ }^{50}$ This research highlighting GPR6 as a possible target for Parkinson's disease treatment is distinctly novel from dopamine-centric therapeutics. An antagonist for GPR6 could thus present as a therapeutic agent for Parkinson's disease.

Instrumental learning: The striatum is a key brain structure for integrating information from the cortex to substantia nigra. Lobo et al. ${ }^{51}$ found that GPR6 is essential for regulation of cAMP production in striatal medium spiny neurons in vitro, owing to 
the observation that cAMP was reduced in GPR6 knockout neurons. In addition, GPR6 knockout mice demonstrated selective changes in instrumental conditioning. This work suggests that GPR6 is likely key for normal learning processes, as well as a potential target for treatment of neuropsychiatric disorders.

\section{Table 3}

\section{Functional Significance of GPR6}

\begin{tabular}{|l|l|l|}
\hline $\begin{array}{l}\text { Physiological/ } \\
\text { Pathological } \\
\text { Indications }\end{array}$ & \multicolumn{1}{|c|}{ Significant Findings } & Source \\
\hline $\begin{array}{l}\text { Neurite } \\
\text { outgrowth }\end{array}$ & $\begin{array}{l}\text { GPR6 overexpression increases neurite outgrowth of } \\
\text { cerebellar granule neurons }\end{array}$ & Tanaka et al. $^{29}$ \\
\hline $\begin{array}{l}\text { Alzheimer's } \\
\text { disease }\end{array}$ & $\begin{array}{l}\text { GPR6 can be upregulated via a C1q-mediated method; } \\
\text { GPR6 is crucial for the C1q-mediated neuroprotection } \\
\text { against amyloid- } \beta \text {-induced neurotoxicity }\end{array}$ & Benoit et al. $^{49}$ \\
\hline $\begin{array}{l}\text { Parkinson's } \\
\text { disease }\end{array}$ & $\begin{array}{l}\text { GPR6-deficient mice show increased striatal dopamine and } \\
\text { reduced dyskinesia in a Parkinson's disease model }\end{array}$ & Oeckl et al. $^{50}$ \\
\hline $\begin{array}{l}\text { Instrumental } \\
\text { learning }\end{array}$ & $\begin{array}{l}\text { GPR6 regulates cAMP production in striatal medium spiny } \\
\text { neurons, and is involved in instrumental conditioning }\end{array}$ & Lobo et al. $^{51}$ \\
\hline
\end{tabular}

GPR6 $=\mathrm{G}$ protein-coupled receptor $6 ; \mathrm{C} 1 \mathrm{q}=\mathrm{C} 1 \mathrm{q}$ protein complex of the innate immune complement system 


\section{GPR12}

Neurite outgrowth and neuronal development: The lab of Ignatov et al. ${ }^{19}$ showed that the lysophospholipid SPC is a high-affinity ligand for GPR12 (Table4). By in situ hybridization on embryonal and adult mice brains, they determined that GPR12 transcripts were present in the embryonal brain with a high concentration in areas of neuronal differentiation. In adult mouse brains, GPR12 was identified in the limbic system. In vitro cell culture revealed that embryonal cerebral cortical neurons had increased synaptic contacts following SPC treatment, and HT22 hippocampal cells increased cell proliferation and clustering in response to SPC. These results led the lab to conclude that by interacting with GPR12, SPC is able to positively influence the proliferation of neuronal precursor cells and the differentiation and maturation process of post-mitotic neurons.

As with GPR3 and GPR6, Tanaka et al. ${ }^{29}$ showed that GPR12 overexpression also increased neurite outgrowth. In fact, GPR12-mediated outgrowth was the most prominent of the three receptors. They further showed that GPR12 activity on neurite outgrowth depends on $\mathrm{G}_{\mathrm{s}}$ protein and cAMP- dependent protein kinase. In experiments in which GPR3 was knocked down, GPR12 also rescued neurite outgrowth. However, similar to GPR6, GPR12 exhibits low expression in rat cerebellar granule neurons. ${ }^{29,36,52}$

In 2012, Lu et al. ${ }^{24}$ demonstrated that GPR12 induces neurite outgrowth in PC12 cells. The consequences of GPR12 overexpression on PC12 cells were studied by transfecting PC12 cells with recombinant human GPR12. They showed that GPR12 overexpression instigated the differentiation of PC12 cells into neuron-like cells with increased size of the cell and neurite generation. The researchers propose that a possible 
mechanism for this phenotype is the activation of ERK1/2 signaling and a substantial increase in the expression of multiple genes related to neurite outgrowth.

GPR12: obesity and metabolic disorders

Bjursell et al. ${ }^{53}$ investigated the importance of GPR12 in metabolism. They found that food intake was not significantly affected in GPR12 knockout mice compared to wildtype mice. However, the GPR12 knockout mice exhibited higher body weight and body fat mass, lower respiratory exchange ratio, hepatic steatosis, and dyslipidemia. The authors concluded that GPR12 plays a significant role in energy balance, which is supported by the fact that GPR12 knockout mice developed obesity and lower energy expenditure.

Oocyte maturation: Hinckley et al. ${ }^{13}$ studied GPR12 expression and its role in oocyte meiotic arrest. GPR12 mRNA is expressed in both rat and mouse oocytes. They demonstrated that GPR12 expression in oocytes prevents meiotic maturation, whereas downregulation of GPR12 allows meiotic resumption. Stimulating oocytes with the putative ligands S1P and SPC led to maturation. It appears from their findings that GPR12 is important for maintenance of meiotic arrest in oocytes.

Cell survival and proliferation: Lu et al. ${ }^{54}$ demonstrated that GPR12 regulates cell proliferation and survival in HEK293 cells. Upon overexpression of GPR12, cell proliferation increased and cell survival was enhanced under serum deprivation conditions. Furthermore, when GPR12 was overexpressed they found activation of extracellular signal-regulated protein kinase signaling, increased total ERK1/2, and increased B cell lymphoma/ leukemia-2 expression. 
Cancer: Keratin $8(\mathrm{~K} 8)$ is involved in cancer cell migration and invasion by changing the viscoelasticity of cancer cells. ${ }^{55}$ Park et al. ${ }^{56}$ showed that overexpression of GPR12 induces K8 phosphorylation and reorganization, and silencing of the receptor reduces both of these $\mathrm{K} 8$ processes. These data indicate that GPR12 may be a potential target for prevention of metastasis by developing of compounds that are able to block GPR12.

Table 4

Functional Significance of GPR12

\begin{tabular}{|c|c|c|}
\hline $\begin{array}{l}\text { Physiological/ } \\
\text { Pathological } \\
\text { Indications }\end{array}$ & Significant Findings & Source \\
\hline \multirow{3}{*}{$\begin{array}{l}\text { Neurite } \\
\text { outgrowth/ } \\
\text { neuronal } \\
\text { survival }\end{array}$} & $\begin{array}{l}\text { SPC interacts with GPR12 and promotes the proliferation of } \\
\text { neuronal precursor cells and the maturation of post-mitotic } \\
\text { neurons }\end{array}$ & $\begin{array}{l}\text { Ignatov et } \\
\text { al. }{ }^{19}\end{array}$ \\
\hline & GPR12 overexpression promotes neurite outgrowth & $\begin{array}{l}\text { Tanaka et } \\
\text { al. }^{29}\end{array}$ \\
\hline & GPR12 initiates neurite outgrowth in PC12 cells & Lu et al. ${ }^{24}$ \\
\hline $\begin{array}{l}\text { Obesity and } \\
\text { metabolic } \\
\text { disorders }\end{array}$ & $\begin{array}{l}\text { GPR12 knock-out mice display increased dyslipidemia and } \\
\text { obesity }\end{array}$ & $\begin{array}{l}\text { Bjursell et } \\
\text { al. }^{53}\end{array}$ \\
\hline $\begin{array}{l}\text { Oocyte } \\
\text { maturation }\end{array}$ & $\begin{array}{l}\text { GPR12 overexpression in oocytes leads to meiotic arrest, } \\
\text { whereas GPR12 downregulation allows meiotic resumption }\end{array}$ & $\begin{array}{l}\text { Hinckley et } \\
\text { al. }{ }^{13}\end{array}$ \\
\hline $\begin{array}{l}\text { Cell survival } \\
\text { and } \\
\text { proliferation }\end{array}$ & $\begin{array}{l}\text { GPR12 enhances cell proliferation and survival in HEK293 } \\
\text { cells }\end{array}$ & Lu et al. ${ }^{54}$ \\
\hline Cancer & $\begin{array}{l}\text { GPR } 12 \text { promotes keratin } 8 \text { phosphorylation and reorganization, } \\
\text { reducing cancer cell viscoelasticity }\end{array}$ & Park et al. ${ }^{56}$ \\
\hline
\end{tabular}




\section{CHAPTER III}

\section{GPR3 AND GPR6, NOVEL MOLECULAR TARGETS FOR CANNABIDIOL}

\section{A. Introduction}

The superfamily of G-protein-coupled receptors (GPCRs) is one of the largest and most studied families of proteins ${ }^{15,57}$. Its members respond to an extensive panel of diverse ligands and participate in an extraordinary numbers of physiological functions 15,57 .

The orphan G protein coupled receptors GPR3 and GPR6 were originally cloned in the mid1990s ${ }^{1,9,15,16,57}$. Both GPR3 and GPR6 are constitutively active and couple to $\mathrm{G}_{\mathrm{s}}$ proteins ${ }^{20,22,57,58}$. However, for a long time these receptors are devoid of a known endogenous ligand, and therefore they have been classified as orphan GPCRs.

Both GPR3 and GPR6 are expressed in the central nervous system, and have been implicated in health and disease of the brain. GPR3 alters emotional behaviors ${ }^{30}$, modulates early phases of cocaine reinforcement ${ }^{39}$, involves in the development of neuropathic pain and regulates morphine-induced antinociception ${ }^{38}$. GPR6 participates in instrumental learning, and ${ }^{51}$, and GPR6 may serve as a therapeutic target for Parkinson's disease $^{50}$, as well as schizophrenia ${ }^{59}$. Both GPR3 and GPR6 expression are shown to be involved neurite outgrowth ${ }^{29}$. Furthermore, both GPR3 and GPR6 may play roles in Alzheimer's disease. GPR3 promotes the production of amyloid- $\beta^{14}$, whereas GPR6 plays a neuroprotective role in amyloid- $\beta$ toxicity ${ }^{49}$. Regarding the possible ligands for

${ }^{1}$ This chapter has been published previously Laun, A. S. \& Song, Z. H. GPR3 and GPR6, novel molecular targets for cannabidiol. Biochem Biophys Res Commun 490, 17-21, doi:10.1016/j.bbrc.2017.05.165 (2017). 
GPR3 and GPR6, Uhlenbrock and co-workers identified sphingosine-1-phosphate (S-1P) as an endogenous ligand for GPR3 and GPR6 by demonstrating that S-1-P can induce cAMP production and $\mathrm{Ca}^{2+}$ mobilization in HEK293 cells transfected with this receptor ${ }^{20,60}$. This result was further supported for GPR6 in a later publication, since S1P was shown to be a high affinity ligand that increased calcium mobilization mediated by GPR6 ${ }^{17}$. However, the claim of S-1-P as an endogenous ligands for GPR3 and GPR6 has been challenged by a number of research groups because they failed to observe a specific S-1P-induced response in cells expressing either GPR3 ${ }^{14,30,61}$ or GPR6 ${ }^{61}$. Since the controversy persists, GPR3 and GPR6 are still considered orphan GPCRs.

Despite being orphans, GPR3 and GPR6 share about 35\% amino acid sequence identity in the transmembrane region with the $\mathrm{CB} 1$ and $\mathrm{CB} 2$ cannabinoid receptors ${ }^{62,63}$. In fact, Lee ${ }^{62,63}$ called these orphans the "cannabinoid receptor-like orphan GPCRs". In this study we tested various phytocannabinoids and endocannabinoids for their potential effects on GPR3 and GPR6 using a $\beta$-arrestin2 recruitment assay.

\section{B. Materials and Methods}

Materials: The PathHunter ${ }^{\mathrm{TM}}$ eXpress kits containing Chinese hamster ovary (CHO)-K1 cells co-expressing EA- $\beta$-arrestin2 human and GPR3-PK/GPR6-PKwere purchased from DiscoverX (Fremont, CA). All cannabinoid ligands were purchased from Cayman Chemical (Ann Arbor, MI).

Pathhunter ${ }^{\mathrm{TM}} \beta$-arrestin2 recruitment assays: PathHunter ${ }^{\mathrm{TM}}$ eXpress kits were used to measure GPR3- or GPR6-mediated $\beta$-arrestin2 recruitment following manufacturer's instructions. In this system, Chinese hamster ovary (CHO)-K1 cell line are stably expressing the GPR3/GPR6 receptors which were fused to a "ProLink (PK)" fragment of 
$\beta$-galactosidase to form GPR3-PK/GPR6-PK. The remaining sequence of $\beta$-galactosidase enzyme acceptor (EA) was linked to $\beta$-arrestin2 to form EA- $\beta$-arrestin2. Recruitment of $\beta$-arrestin2 by receptor activation causes complementation of the two enzyme fragments. Levels of the active enzyme are the direct result of $\beta$-arrestin2 recruitment caused by receptor activation and quantified using the PathHunter detection reagent containing $\beta$ galactosidase substrates. Cells were plated in DiscoverX cell plating reagent1 in 384-well plates and cultured for 24-48 hours prior to experimentation in a humidified atmosphere at $37^{\circ} \mathrm{C}$ and $5 \% \mathrm{CO}_{2}$. Cannabinoid ligands were diluted in cell plating reagent1. Cells were then incubated with ligand at $37^{\circ} \mathrm{C}$ following manufacturer's recommendations, followed by incubation with detection reagent in the dark for 1 hour at $23^{\circ} \mathrm{C}$. Luminescence signal was then detected using a TECAN GENios Pro microplate reader.

Data Analysis: Ligand-induced changes in $\beta$-arrestin2 recruitment to GPR3 and GPR6 were expressed as percent basal relative luminescence units, which was calculated by dividing luminescence readings in the presence of ligands by basal luminescence readings, times 100 . Concentration-response curves were generated by performing nonlinear regression analysis using GraphPad Prism (GraphPad Software, La Jolla, CA). Data were analyzed using one-way analysis of variance (ANOVA) followed by NewmanKeuls post-test. A $p<0.05$ was considered statistically significant. Data points shown are presented as mean $\pm \mathrm{SEM}$, and were obtained from three independent experiments performed in quadruplicate.

C. Result 
The effects of endocannabinoids on GPR3 and GPR6: To determine whether endocannabinoids are capable of altering $\beta$-arrestin2 recruitment to GPR3/GPR6, $\beta$ arrestin2 recruitment assays were performed using $0.1 \mu \mathrm{M}$ and $1 \mu \mathrm{M}$ of endocannabinoids anandamide (AEA), 2-arachidonoylglycerol (2-AG), virodhamine, and noladin ether (NE). None of the endocannabinoids tested had any significant effects on $\beta$ arrestin2 recruitment to either GPR3 (Fig. 1A) or GPR6 (Fig. 1B) at the two concentrations tested.
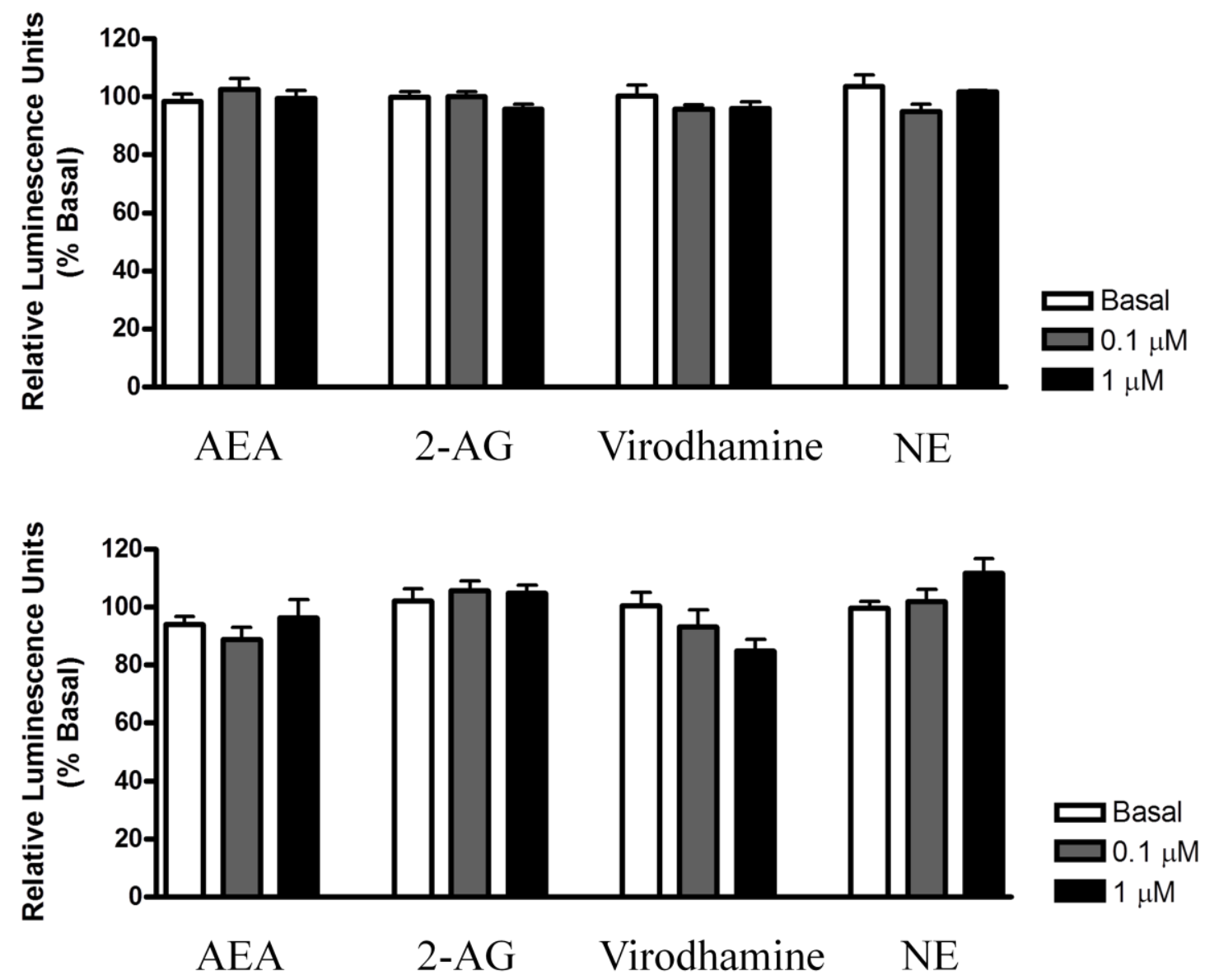

Figure 1. Effects of endocannabinoids on b-arrestin2 recruitment to GPR3 and GPR6. (A) Effects of endocannabinoids on $\beta$-arrestin2 recruitment to GPR3. (B) Effects of endocannabinoids on $\beta$-arrestin2 recruitment to GPR6. Results are expressed as percent of basal relative luminescence units. Data shown represent the mean \pm SEM of three experiments performed in quadruplicate. Data were analyzed by one-way analysis of variance followed by Newman-Keuls post-test. 
The effects of phytocannabinoids on GPR3 and GPR6: To determine whether phytocannabinoids are capable of changing $\beta$-arrestin2 recruitment to GPR3/GPR6, barrestin2 recruitment assays were performed using $0.1 \mu \mathrm{M}$ and $1 \mu \mathrm{M}$ of phytocannabinoids cannabigerol (CBG), D9-tetrahydrocannabinol (THC), cannabidiol (CBD), cannabinol (CBN), and cannabichromene (CBC). CBD significantly reduced $\beta$ arrestin2 recruitment to GPR3 at the $1 \mu \mathrm{M}$ concentration (Fig. 2A). CBD also significantly reduced $\beta$-arrestin2 recruitment to GPR6 at both the $0.1 \mu \mathrm{M}$ and $1 \mu \mathrm{M}$ concentrations (Fig. 2B). In contrast, none of the other phytocannabinoids tested had any significant effects on $\beta$-arrestin2 recruitment to either GPR3 (Fig. 2A) or GPR6 (Fig. 2B) at the two concentrations tested. 

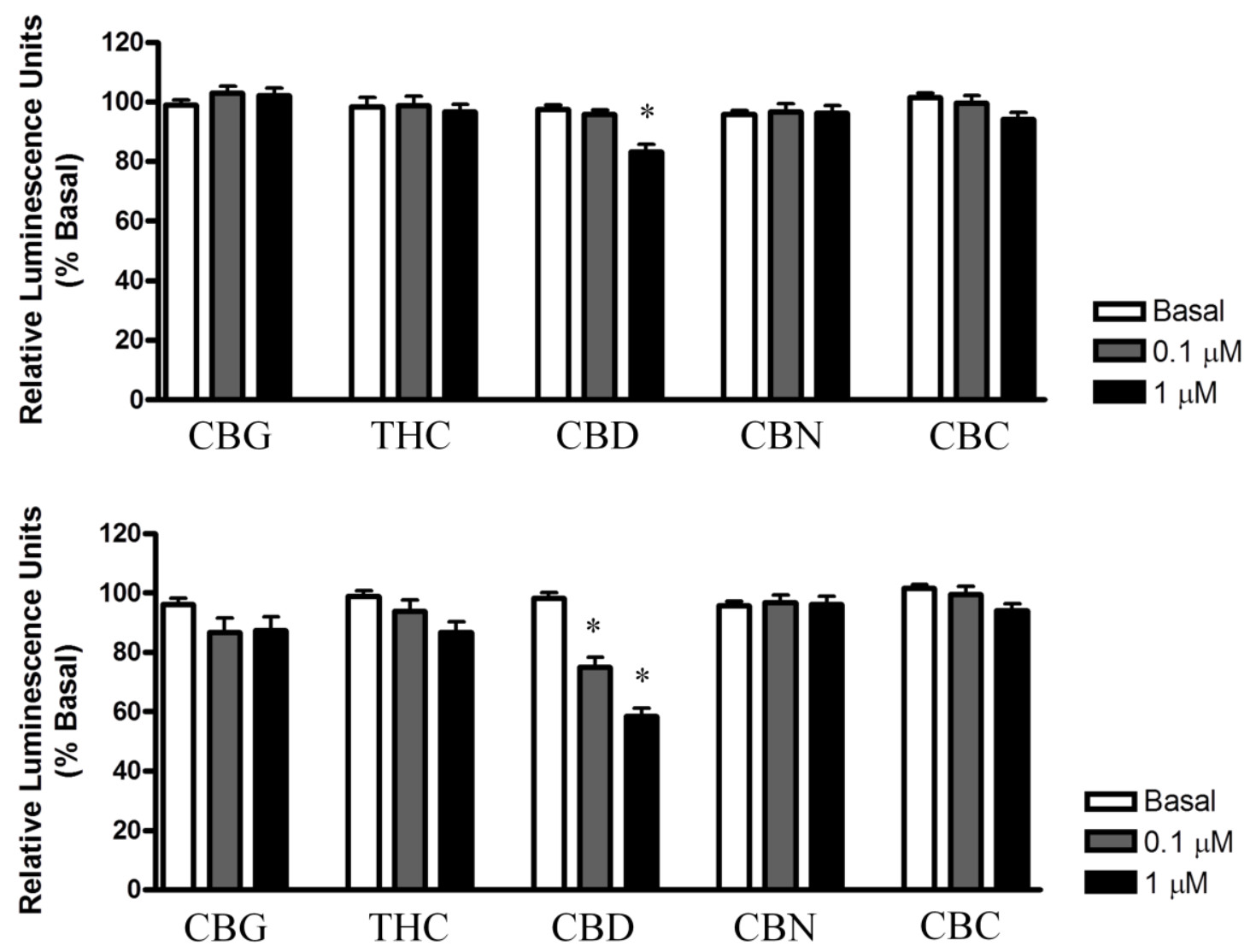

Figure 2. Effects of phytocannabinoids on $\beta$-arrestin2 recruitment to GPR3 and GPR6. (A) Effects of phytocannabinoids on $\beta$-arrestin2 recruitment to GPR3. (B) Effects of phytocannabinoids on $\beta$-arrestin2 recruitment to GPR6. Results are expressed as percent of basal relative luminescence units. Data shown represent the mean \pm SEM of three experiments performed in quadruplicate. Data were analyzed by one-way analysis of variance followed by Newman-Keuls post-test $(* \mathrm{P}<0.05$ compared to basal recruitment). 
Concentration-dependence of the effects of cannabidiol on GPR3 and GPR6: In the third set of experiments, we performed a concentration dependence study of the effects of $\mathrm{CBD}$ on $\beta$-arrestin2 recruitment to GPR3/GPR6. As shown in Fig. 3, CBD concentration-dependently decreased $\beta$-arrestin 2 recruitment to both GPR3 and GPR6. CBD had similar efficacy on GPR3 and GPR6, with $\beta$-arrestin2 recruitment inhibited by $39.08(31.83-46.32) \%$ and $44.12(35.80-52.53) \%$ of basal level, respectively. However, CBD exhibited significantly lower potency at GPR3 than at GPR6, with EC50 (95\% CI) values of $1.22(0.59-2.51) \mu \mathrm{M}$ and $0.18(0.061-0.53) \mu \mathrm{M}$ respectively.

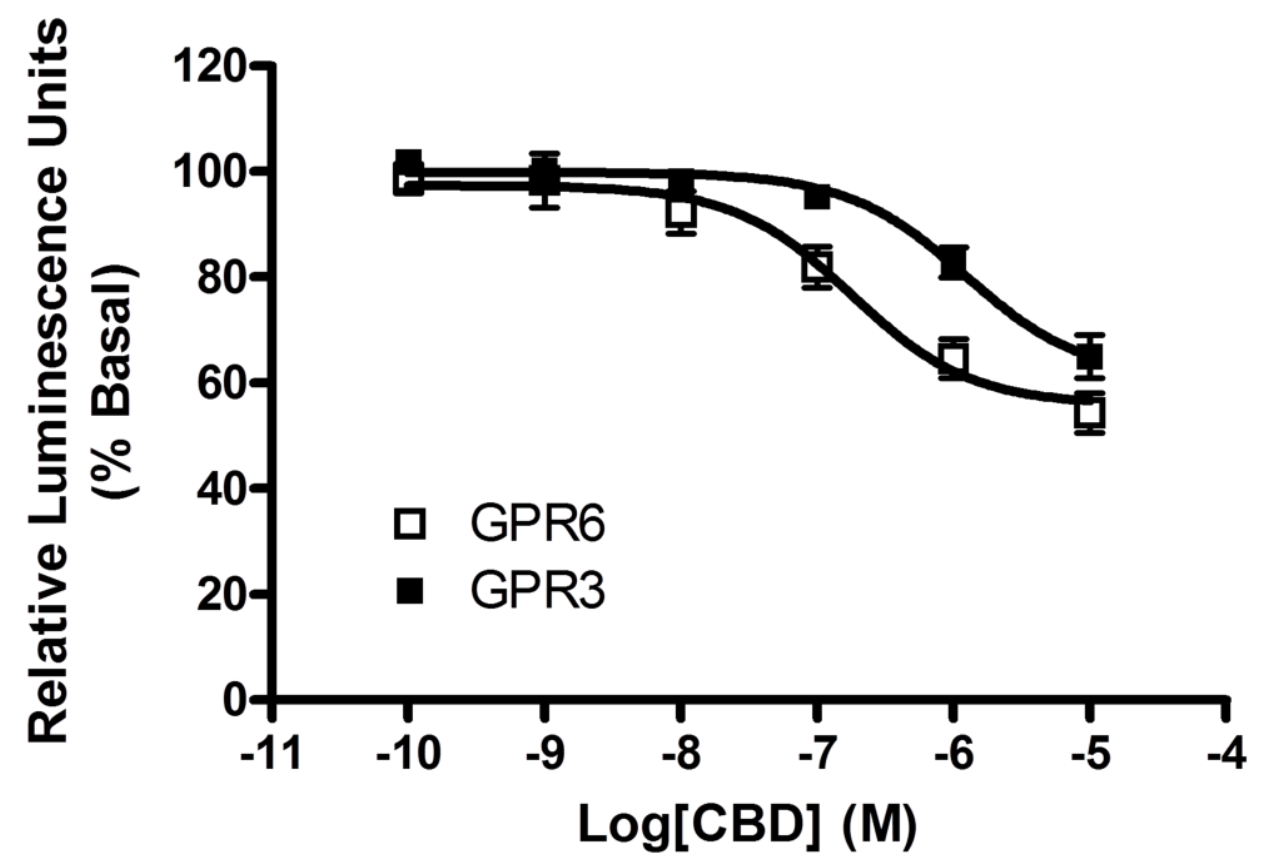

Figure 3. Concentration-response curves of cannabidiol in inhibiting $\beta$-arrestin 2 recruitment to GPR3 and GPR6.

Results are expressed as percent of basal relative luminescence units. Data points shown represent the mean \pm SEM of three experiments performed in quadruplicate. 


\section{Discussion}

In the present study we have used the DiscoverX PathHunter $\beta$-arrestin2 recruitment assay to test various encannabinoids and phytocannabinoids against the orphan receptors GPR3 and GPR6. We chose this assay based on the facts that it has several advantages comparing with other kinds of assays. The first advantage of the $\beta$ arrestin 2 recruitment assay is that it gives reliable signal regardless of $G$ protein coupling (Gs, Gi or Gq). Thus the measurement is direct and does not rely on measurement of second messengers ${ }^{64}$. The second advantage of the PathHunter $\beta$-arrestin 2 recruitment assay is that there are no off target receptor signal, since the signal generated depends only on complementation of the receptor-PK and EA- $\beta$-arrestin $2{ }^{64}$.

Our first objective was to test the potential effects selected endocannabinoids on $\beta$-arrestin2 recruitment to both GPR3 and GPR6 receptors. Two well established endocannabinoids 2-AG and AEA, as well as two putative endocannabinoids virodhamine and NE, were used. Virodhamine is similar in structure to AEA though it contains arachidonic acid and ethanolamide joined by an ester linkage instead of an amide linkage as in $\mathrm{AEA}^{65}$. $\mathrm{NE}$ is similar in structure to 2-AG though it contains arachidonic acid and glycerol joined by an ether linkage instead of an ester linkage as in $2-\mathrm{AG}^{66} 67$. At a concentration of $1 \mu \mathrm{M}$, none of the endocannabinoids tested significantly altered $\beta$-arrestin 2 recruitment to either GPR3 or GPR6. These data suggest that none of endocannabinoids tested behaves as ligands for GPR3 or GPR6.

Secondly, we tested the effects of five major phytocannabinoids (THC, CBD, $\mathrm{CBN}, \mathrm{CBC}$, and $\mathrm{CBG}$ ), on $\beta$-arrestin2 recruitment to GPR3/GPR6. Among the phytocannabinoids that were tested, only CBD significantly reduced $\beta$-arrestin2 
recruitment to both GPR3 and GPR6 at a concentration of $1 \mu \mathrm{M}$. Therefore, here we identified for the first time that GPR3 and GPR6 are novel targets for CBD.

Thirdly, we examined the concentration-dependence of CBD as an inverse agonist for GPR3 and GPR6. We found that CBD inhibited $\beta$-arrestin2 recruitment to both GPR3 and GPR6 in a concentration-dependent manner, thus confirming CBD is an inverse agonist at both GPR3 and GPR6.

Cannabidiol (CBD) is one of the major components of marijuana ${ }^{68,69}$. Unlike tetrahydrocannabinol (THC), the major psychoactive constituent of cannabis, CBD is a non-psychotropic phytocannabinoid ${ }^{68,69}$. CBD has been proposed to act on many targets, including enzymes and receptors. For example, CBD has been shown to act, with low affinity, on a variety of GPCRs. CBD has low affinity for $\mathrm{CB} 1$ and $\mathrm{CB} 2{ }^{70}$, but Pertwee ${ }^{71}$ showed that it was able to antagonize the effect of CB1 agonists indirectly. Laprarie et al ${ }^{72}$ supported this finding when they identified CBD as a negative allosteric regulator of CB1. In addition, CBD has been demonstrated to be an agonist at serotonin 5HT1a receptor ${ }^{73}$, an antagonist at GPR55 ${ }^{74}$, and an allosteric modulator of the mu and delta opioid receptors ${ }^{75}$. In this study, we identified GPR3 and GPR6 as a novel targets for CBD. This indicates a new mechanism of action for CBD in addition to the previously identified targets

GPR3 has been identified as a modulator of amyloid- $\beta$ generation in a high throughput functional genomics screen designed to identify potential therapeutic targets for Alzheimer's disease (AD) ${ }^{14}$. Further, overexpression of GPR3 increases amyloid $\beta$ production through a $\beta$-arrestin2 mediated pathway ${ }^{26}$. Thus, in the case of Alzheimer's disease, inverse agonist that reduces the $\beta$-arrestin2 recruitment to GPR3 may reduce 
amyloid- $\beta$ generation. In the current study, we have demonstrated for the first time that CBD acts an inverse agonist to inhibit $\beta$-arrestin2 recruitment to GPR3. These data suggest that CBD may have the potential as a therapeutic agent for Alzheimer's disease by acting as an inverse agonist on GPR3.

GPR6 has been suggested as a therapeutic target for Parkinson's disease. ${ }^{50}$. Oeck1 et al showed that GPR6 knockout decreases cAMP production, enhances motor activity and decreases abnormal movements in a Parkinson's disease mouse model. They suggest that GPR6 may provide a target for treatment of Parkinson's disease as an alternative for dopamine replacement. In this case, an inverse agonist of GPR6 may reduce dyskinesia and improve motor activity in individuals with Parkinson's disease. In this study, we have demonstrated that $\mathrm{CBD}$ acts as an inverse agonist for GPR6. Our novel finding of $\mathrm{CBD}$ as an inverse agonist for GPR6 may provide an additional mechanisms of action for the neuroprotective effect of CBD seen in Parkinson's disease models ${ }^{76,77}$.

In summary, we have revealed for the first time that non-psychoactive phytocannbibbinoids CBD acts as a novel inverse agonist on both GPR3 and GPR6. CBD has been demonstrated to have potential therapeutic effects for a number of neurological disorders ${ }^{78}$. Our discovery that GPR3 and GPR6 as novel targets for CBD indicates that some of the potential therapeutic effects of CBD, such as for Alzheimer's disease and Parkinson's disease, may be mediated through either GPR3 or GPR6. 


\section{CHAPTER IV}

\section{FURTHER STUDY OF CBD}

A. Structure activity relationship study of CBD

GPR3, GPR6, and GPR12 are considered orphan receptors because their endogenous agonists have yet to be confirmed. However, these orphan receptors share $35 \%$ amino acid sequence identity in the transmembrane regions with the CB1 and CB2 cannabinoid receptors. ${ }^{62}$ Because GPR3, GPR6, and GPR12 are phylogenetically related to cannabinoid receptors, we recently tested various classes of cannabinoids for their potential effects on these three orphan receptors.

We first sought to confirm the constitutive activity of GPR3, GPR6, and GPR12. Our data showed that all three receptors were constitutively active. ${ }^{6,7}$ Subsequently, we tested the effects of cannabinoids on GPR3 and GPR6 mediated $\beta$-arrestin 2 recruitment, and GPR12 mediated cAMP accumulation.

We tested two well-established endocannabinoids, 2-arachidonoyl glycerol (2AG) and anandamide (AEA), as well as two putative cannabinoids, noladin ether (NE) and virodhamine. Of the four, none had any significant effect on $\beta$-arrestin 2 recruitment to either GPR3 or GPR6. Similarly, in cells expressing GPR12, none of the endocannabinoids tested altered cAMP accumulation up to $100 \mu \mathrm{M}$ concentrations.

We also tested five phytocannabinoids: $\Delta^{9}$-tetrahydrocannabinol ( $\Delta 9$-THC), cannabidiol $(\mathrm{CBD})$, cannabinol $(\mathrm{CBN})$, cannabigerol $(\mathrm{CBG})$, and cannabichromene 
(CBC). The majority of phytocannabinoids tested showed no significant effect on $\beta$-arrestin2 recruitment to either GPR3 or GPR6; CBD, being the exception, concentration-dependently reduced $\beta$-arrestin2 recruitment to both GPR 3 and GPR6. ${ }^{6}$ We also found that CBD exhibited higher potency for GPR6 than for GPR3 ${ }^{6}$ With regards to GPR12, most of the phytocannabinoids tested had no effect up to $100 \mu \mathrm{M}$, again with the exception of $\mathrm{CBD}$, which significantly decreased cAMP accumulation concentrationdependently with an EC50 of about $10 \mu \mathrm{M}^{7}$ Together, these results demonstrate for the first time that GPR3, GPR6, and GPR12 are novel molecular targets for CBD, and CBD is a new inverse agonist for this family of orphan receptors. ${ }^{6,7}$

Building on this discovery, we next conducted a structure-activity relationship analysis of CBD as an inverse agonist of GPR3, GPR6, and GPR12. We designed the study around CBD analogues, with changes made to either the aliphatic side chain or the free hydroxyl groups. Cannabidivarin (CBDV) exchanges the pentyl for a propyl side chain, and O-1821 substitutes the pentyl for a methyl side chain. In contrast, cannabidiol2',6'-dimethyl ether (CBDD) contains the same pentyl side chain, but substitutes the 2',6'- hydroxyl groups with methoxyl groups. Our data showed all three derivatives to be less potent than the original structure of CBD. Thus, these data demonstrate that both the pentyl side chain and the free hydroxyl groups are essential for the inverse agonism of CBD on GPR3, GPR6, and GPR12., 5 Despite the finding of CBD action on these receptors, GPR3, GPR6, and GPR12 remain orphans since by definition they do not have a confirmed endogenous ligand. It is possible that by binding to the receptor, CBD is blocking the effects of an unidentified, endogenous agonists, and is therefore a neutral antagonist, rather than an inverse agonist for GPR3, GPR6, or GPR12. This point is 
unsettled, and cannot be discounted without further work. While we acknowledge this possibility, we believe it is unlikely the case for the following two reasons. Firstly, the original finding of S1P/SPC agonism on these orphan receptors have been challenged by a number of independent groups, who could not reproduce the reported results of S1P/SPC agonisim. ${ }^{14,28,30}$ Secondly, in our hands neither serum deprivation nor charcoal stripped serum affected either the constitutive activity of these orphan receptors, or the CBD-induced reduction of constitutive activity. Based on these two reasons, we believe that CBD, is truly an inverse agonist on GPR3, GPR6 and GPR12.

B. Molecular scaffold for future development of potent ligands

CBD is not a potent ligand for GPR3 $\left(\mathrm{EC}_{50} \sim 1 \mu \mathrm{M}\right)$ and GPR6 $\left(\mathrm{EC}_{50} \sim 100 \mathrm{nM}\right)$ in $\beta$-arrestin2 recruitment assay. ${ }^{6}$ Also, it is not a potent ligand for GPR12-mediated cAMP accumulation $\left(\mathrm{EC}_{50} \sim 10 \mu \mathrm{M}\right){ }^{7} \quad$ Nevertheless, $\mathrm{CBD}$ still provides a molecular scaffold upon which structural changes can be made to develop new, potentially more potent and efficacious ligands for GPR3, GPR6, and GPR12.

Our collaborators, Morales, Hurst, and Reggio ${ }^{3}$ have recently developed an in silico model of GPR3. In developing the model, they hope to gain insight into the structure and function of GPR3 and use the model as a powerful tool for development of high affinity/potency ligands for the receptor. Based on our experimental data of CBD as an inverse agonist, as well as our CBD structure-activity relationship data (i.e. modifications to the aliphatic side chain and free hydroxyl groups), CBD and its analogues can be docked within the GPR3 model. From docking, chemical modifications to the CBD scaffold can be designed, novel ligands can be synthesized, and these new compounds can be tested experimentally, with the goal of producing highly potent 
ligands acting on GPR3. The highly potent ligands (theoretically, inverse agonists) can then be used as research tools to study the functions of GPR3 and perhaps can be developed to therapeutic agents (e.g. for the treatment of Alzheimer's disease and infertility). 


\section{CHAPTER V}

\section{FUTURE STUDY OF CBD AND CONCLUDING REMARKS}

\section{A. Potential Significance and Implications of CBD}

CBD has been identified to have a wide array of health benefits. Our finding of novel targets for $\mathrm{CBD}$ prompted further research. While reviewing the literature, some overlap existed between which conditions GPR3, GPR6, and GPR12 may have a role, and those diseases for which CBD has benefit. The link is not direct, and no evidence supports that $\mathrm{CBD}$ acts through these receptors to mediate the effect. Knockout data showing CBD effects are absent in cells/tissues lacking these receptors would greatly benefit study of the receptors, study of CBD, and study of the diseases. In this section, we highlight some of the conditions for which $\mathrm{CBD}$ has exhibited benefit, and point out parallels between GPR3, GPR6 and GPR12 in the hopes that this is a new and exciting area of future research.

Alzheimer's disease: Within the last 20 years, CBD has been suggested to be beneficial for Alzheimer's disease therapy. ${ }^{79}$ Cheng et al. ${ }^{80}$ studied the effects of CBD on various cognitive parameters in a mouse model of Alzheimer's disease. After treatment with CBD for 3 weeks, the mice were observed to undergo a reversal of cognitive deficits. This study was the first to demonstrate that CBD may be an effective treatment for Alzheimer's disease. 
With regards to its mechanism, it is well documented that CBD has antiinflammatory, neuroprotective, and antioxidant properties. Furthermore, CBD has been shown to regulate microglial activation, reduce tau hyperphosphorylation, prevent neurodegeneration, and promote neurogenesis. ${ }^{79}$

As mentioned above, GPR3 overexpression increases $A \beta$ generation through $\beta$ arrestin2, whereas GPR3 knockout decreases A $\beta$ pathology. ${ }^{14,26}$ Therefore an inverse agonist for $\beta$-arrestin2 recruitment via GPR3 may reduce $A \beta$ generation. Our new finding that $\mathrm{CBD}$ acts as an inverse on GPR3 suggests that this receptor presents a novel mechanism through which CBD can produce its therapeutic effects for Alzheimer's disease. While still unconfirmed, this proposed novel mechanism of action of CBD in Alzheimer's disease is consistent with previous reports of CBD relieving cognitive deficits in Alzheimer's disease mice. ${ }^{80}$

Parkinson's disease: Using animal models of Parkinson's disease (6hydroxydopamine treated animals), CBD has been shown to reduce the severity of dopamine depletion and the inhibition of tyrosine hydroxylase activity in vivo. It was suggested that this neuroprotective role of CBD is either anti-inflammatory or antioxidant in nature. It was also pointed out that the mechanism through which CBD acts may be a non-CB1/CB2 mechanism. ${ }^{77}$

As reviewed above, GPR6 is a potential therapeutic target for Parkinson's disease. In 6-hydroxydopamine-treated GPR6 knockout mice, the level of dopamine depletion was also reduced compared with wild-type mice, which correlated with improved motor activities while decreasing abnormal movements. ${ }^{50}$ It is apparent from this result that an inverse agonist for GPR6 may be beneficial for Parkinson's disease treatment. Our 
finding that GPR6 is a novel molecular target for CBD further indicates this phytocannabinoid for Parkinson's disease therapy. In addition to previously identified mechanisms, CBD working as an inverse agonist on GPR6 may alter the dopamine levels in striatum and produce neuroprotective effects. Further studies are warranted to elucidate this novel mechanism of CBD action on Parkinson's disease.

Cancer: CBD has been extensively studied for its anti-cancer benefits. CBD has been demonstrated to inhibit the progression of glioblastoma, breast, lung, prostate, and colon cancer ${ }^{81}$. Several mechanism for CBD anti-cancer activity have been identified, including inhibition of cancer cell viability, invasion, and metastasis ${ }^{81}$. With relevance to cancer metastasis, $\mathrm{CBD}$ has been shown to inhibit the migration of several types of cancer cells, including breast cancer, cervical cancer, lung cancer, and glioblastoma. ${ }^{81}$

GPR12 has also been suggested to play a role in cancer metastasis. ${ }^{56}$ Having identified $\mathrm{CBD}$ as a novel inverse agonist for GPR12, our data suggest that CBD may decrease cancer cell migration by acting on GPR12 to change the viscoelasticity of metastatic cancer cells. Our discovery may also provide the initial chemical scaffolds upon which highly potent and efficacious agents acting on GPR12 may be developed with the ultimate goal of preventing cancer metastasis.

Infertility: Regulation of meiotic arrest and resumption are important for fertility. ${ }^{82}$ Normally, cAMP is maintained at high levels in the oocyte to arrest meiosis and halt maturation. However, persistent meiotic arrest limits reproductive performance, and women with premature ovarian aging are at risk for infertility due to unregulated meiotic events. 
$\mathrm{CBD}$ has been identified to have a role in oocyte maturation. Reich et al. ${ }^{83}$ demonstrated that treatment with CBD induced resumption of meiosis in rat oocytes. Furthermore, both GPR $3^{13,42}$ and GPR $12^{13}$ are important for meiotic arrest of oocyte. Since we have recently identified that CBD is an inverse agonist on both GPR ${ }^{6}$ and GPR $12^{7}$, this suggests that the mechanism for CBD to cause the resumption of meiosis in oocytes might be due to its inverse agonistic action on GPR3 and/or GPR12. In addition, our discovery of GPR3 and GPR12 as novel targets for CBD suggests that CBD and its derivatives might be worth exploring as novel therapeutic agents for treating infertility by tightly regulating meiotic arrest and resumption.

CBD is one of the major components of marijuana. ${ }^{69,84}$ Unlike $\Delta 9-T H C$, the major psychoactive constituent of cannabis, CBD is a nonpsychotropic phytocannabinoid. ${ }^{69,84} \mathrm{CBD}$ has been proposed to act on many targets, including enzymes and receptors. For example, CBD has been shown to act, with low affinity, on a variety of GPCRs. CBD has low affinity for CB1 and CB2, ${ }^{70}$ but Pertwee showed that it was able to antagonize the effect of CB1 agonists indirectly. ${ }^{71}$ Laprarie et al. $^{72}$ supported this finding when they identified CBD as a negative allosteric regulator of CB1. In addition, CBD has been demonstrated to be an agonist at serotonin $5 \mathrm{HT} 1 \mathrm{a}^{73,85}$ and $5 \mathrm{HT} 3 \mathrm{a}^{86}$ receptors, an antagonist at GPR55, ${ }^{74}$ and an allosteric modulator of the mu and delta opioid receptors. ${ }^{75}$ Other than working on GPCRs, CBD has also been identified to work as an agonist for PPAR- $\gamma$, a TRPM8 antagonist, an $\alpha_{1}$ and $\alpha_{3}$ glycine receptor agonist, an agonist for TRPV1 and TRPV2 channels, and a TRPA1 antagonist. ${ }^{87}$

The discovery that GPR 3, 6 and 12 are novel targets for CBD occurred very recently. In this section, we have provided potential significance and implications for this 
recent discovery. While CBD has many reported targets, the recent discovery of GPR3, GPR6, and GPR12 as novel targets of CBD gives new perspective into the potential therapeutic effects of CBD and warrants further study.

CBD exhibits variable potency on GPR3, GPR6, and GPR12. The potency of $\mathrm{CBD}$ for GPR12 signaling is poor; the $\mathrm{EC}_{50}$ is about $10 \mu \mathrm{M}$ which is unrealistic for a highly effective drug. ${ }^{7}$ We must recognize that since this potency is so low, it is unlikely to be the sole receptor involved in any conditions CBD may effect. The potency is higher however for GPR3 $\left(\mathrm{EC}_{50} 1 \mu \mathrm{M}\right)$ and GPR6 $\left(\mathrm{EC}_{50} 100 \mathrm{nM}\right){ }^{6}$ The higher potency for these receptors indicates that $\mathrm{CBD}$ may be relevant for some aspects of signaling for these two receptors with GPR6 being the most promising target.

\section{B. Overall Impact and Concluding Remarks}

Misinformation and pseudoscience regarding medicinal use of cannabis, and CBD particularly, is rampant. With the political climate changing, and legalization of cannabis use in an increasing number of states in the U.S., it is imperative that the benefits and consequences of cannabis use be fully understood. Identification of GPR3 and GPR6 as molecular targets of CBD provides more insight into how the drug acts, and may explain some of the unexplained effects $\mathrm{CBD}$ has for various conditions. The information in this thesis and the future studies of CBD will bridge the gap in knowledge between CBD use and the observed benefits.

In this thesis, we have surveyed the current literature on GPR3, GPR6, and GPR12 and in doing so, detailed their most significant roles in physiological functions and pathological processes. Our recent discovery highlights CBD as a novel inverse agonist for these three orphan receptors. Consequently, this offers us a new perspective from which to analyze the new molecular mechanisms of action for CBD. GPR3, GPR6 
and GPR12, being novel molecular targets for CBD, may participate in CBD-induced reduction of $\mathrm{A} \beta$ pathology, alteration of dopamine levels, inhibition of cancer cell migration, and regulation of meiotic arrest and resumption. Additional studies are warranted to further understand how GPR3, GPR6, and GPR12 mediate the CBDinduced functional changes, and to uncover more potent ligands for each of these orphan receptors that can be used as research tools and perhaps novel therapeutic agents for the treatment of Alzheimer's disease, Parkinson's disease, cancer metastasis, and infertility.

${ }^{2}$ The majority of the content within this thesis has been submitted to Acta Pharmacologica Sinica for publication. 


\section{REFERENCES}

1 Song, Z. H., Modi, W. \& Bonner, T. I. Molecular cloning and chromosomal localization of human genes encoding three closely related $\mathrm{G}$ protein-coupled receptors. Genomics 28, 347-349, doi:10.1006/geno.1995.1154 (1995).

2 Kostenis, E. Novel clusters of receptors for sphingosine-1-phosphate, sphingosylphosphorylcholine, and (lyso)-phosphatidic acid: new receptors for "old" ligands. J Cell Biochem 92, 923-936, doi:10.1002/jcb.20092 (2004).

3 Morales, P., Hurst, D. P. \& Reggio, P. H. in Methods in Enzymology Vol. 593 (Elsevier, 2017).

4 Davenport, A. P. et al. Class A Orphans, $<$ http://www.guidetopharmacology.org/GRAC/FamilyDisplayForward?familyId=16> (

5 Song, Z. H. \& Laun, A. S. in 27th Annual Symposium on the Cannabinoids P3-9 (International Cannabinoid Research Society Montreal, QC, Canada, 2017).

6 Laun, A. S. \& Song, Z. H. GPR3 and GPR6, novel molecular targets for cannabidiol. Biochem Biophys Res Commun 490, 17-21, doi:10.1016/j.bbrc.2017.05.165 (2017).

7 Brown, K. J., Laun, A. S. \& Song, Z. H. Cannabidiol, a novel inverse agonist for GPR12. Biochem Biophys Res Commun 493, 451-454, doi:10.1016/j.bbrc.2017.09.001 (2017).

8 Saeki, Y. et al. Molecular cloning of a novel putative G protein-coupled receptor (GPCR21) which is expressed predominantly in mouse central nervous system. FEBS Lett 336, 317-322 (1993).

9 Marchese, A. et al. Cloning of human genes encoding novel G protein-coupled receptors. Genomics 23, 609-618, doi:10.1006/geno.1994.1549 (1994).

10 Iismaa, T. P. et al. Isolation and chromosomal localization of a novel human Gprotein-coupled receptor (GPR3) expressed predominantly in the central nervous system. Genomics 24, 391-394, doi:10.1006/geno.1994.1635 (1994).

11 Eggerickx, D. et al. Molecular cloning of an orphan G-protein-coupled receptor that constitutively activates adenylate cyclase. The Biochemical journal 309 ( Pt 3), 837843 (1995).

12 Zhang, B. et al. The porcine Gpr3 gene: molecular cloning, characterization and expression level in tissues and cumulus-oocyte complexes during in vitro maturation. Mol Biol Rep 39, 5831-5839, doi:10.1007/s11033-011-1393-y (2012).

13 Hinckley, M., Vaccari, S., Horner, K., Chen, R. \& Conti, M. The G-proteincoupled receptors GPR3 and GPR12 are involved in cAMP signaling and maintenance of meiotic arrest in rodent oocytes. Dev Biol 287, 249-261, doi:10.1016/j.ydbio.2005.08.019 (2005). 
14 Thathiah, A. et al. The orphan G protein-coupled receptor 3 modulates amyloidbeta peptide generation in neurons. Science 323, 946-951, doi:10.1126/science.1160649 (2009).

15 Song, Z. H., Young, W. S., 3rd, Brownstein, M. J. \& Bonner, T. I. Molecular cloning of a novel candidate $\mathrm{G}$ protein-coupled receptor from rat brain. FEBS Lett 351, 375-379 (1994).

16 Heiber, M. et al. Isolation of three novel human genes encoding $\mathrm{G}$ proteincoupled receptors. DNA Cell Biol 14, 25-35, doi:10.1089/dna.1995.14.25 (1995).

17 Ignatov, A., Lintzel, J., Kreienkamp, H. J. \& Schaller, H. C. Sphingosine-1phosphate is a high-affinity ligand for the G protein-coupled receptor GPR6 from mouse and induces intracellular $\mathrm{Ca} 2+$ release by activating the sphingosine-kinase pathway. Biochem Biophys Res Commun 311, 329-336 (2003).

18 Eidne, K. A. et al. Cloning, sequencing and tissue distribution of a candidate $\mathrm{G}$ protein-coupled receptor from rat pituitary gland. FEBS Lett 292, 243-248 (1991).

19 Ignatov, A. et al. Role of the G-protein-coupled receptor GPR12 as high-affinity receptor for sphingosylphosphorylcholine and its expression and function in brain development. J Neurosci 23, 907-914 (2003).

20 Uhlenbrock, K., Gassenhuber, H. \& Kostenis, E. Sphingosine 1-phosphate is a ligand of the human gpr3, gpr6 and gpr12 family of constitutively active $\mathrm{G}$ proteincoupled receptors. Cellular signalling 14, 941-953 (2002).

21 Bresnick, J. N. et al. Identification of signal transduction pathways used by orphan g protein-coupled receptors. Assay Drug Dev Technol 1, 239-249, doi:10.1089/15406580360545053 (2003).

22 Martin, A. L., Steurer, M. A. \& Aronstam, R. S. Constitutive Activity among Orphan Class-A G Protein Coupled Receptors. PLoS One 10, e0138463, doi:10.1371/journal.pone.0138463 (2015).

23 Tanaka, S. et al. Developmental expression of GPR3 in rodent cerebellar granule neurons is associated with cell survival and protects neurons from various apoptotic stimuli. Neurobiol Dis 68, 215-227, doi:10.1016/j.nbd.2014.04.007 (2014).

$24 \mathrm{Lu}, \mathrm{X}$., Zhang, N., Dong, S. \& Hu, Y. Involvement of GPR12 in the induction of neurite outgrowth in PC12 cells. Brain Res Bull 87, 30-36, doi:10.1016/j.brainresbull.2011.09.020 (2012).

25 Lowther, K. M., Uliasz, T. F., Gotz, K. R., Nikolaev, V. O. \& Mehlmann, L. M. Regulation of Constitutive GPR3 Signaling and Surface Localization by GRK2 and betaarrestin-2 Overexpression in HEK293 Cells. PLoS One 8, e65365, doi:10.1371/journal.pone.0065365 (2013).

26 Thathiah, A. et al. beta-arrestin 2 regulates Abeta generation and gammasecretase activity in Alzheimer's disease. Nature medicine 19, 43-49, doi:10.1038/nm.3023 (2013).

27 Nelson, C. D. \& Sheng, M. Gpr3 stimulates Abeta production via interactions with APP and beta-arrestin2. PLoS One 8, e74680, doi:10.1371/journal.pone.0074680 (2013).

28 Yin, H. et al. Lipid G protein-coupled receptor ligand identification using betaarrestin PathHunter assay. J Biol Chem 284, 12328-12338, doi:10.1074/jbc.M806516200 (2009). 
29 Tanaka, S., Ishii, K., Kasai, K., Yoon, S. O. \& Saeki, Y. Neural expression of G protein-coupled receptors GPR3, GPR6, and GPR12 up-regulates cyclic AMP levels and promotes neurite outgrowth. J Biol Chem 282, 10506-10515, doi:10.1074/jbc.M700911200 (2007).

30 Valverde, O. et al. GPR3 receptor, a novel actor in the emotional-like responses. PLoS One 4, e4704, doi:10.1371/journal.pone.0004704 (2009).

31 Ye, C. et al. Identification of a novel small-molecule agonist for human $\mathrm{G}$ protein-coupled receptor 3. J Pharmacol Exp Ther 349, 437-443, doi:10.1124/jpet.114.213082 (2014).

32 Jensen, T. et al. The identification of GPR3 inverse agonist AF64394; the first small molecule inhibitor of GPR3 receptor function. Bioorg Med Chem Lett 24, 51955198, doi:10.1016/j.bmcl.2014.09.077 (2014).

33 Lin, Z. J. et al. GPR12 selections of the metabolites from an endophytic Streptomyces sp. associated with Cistanches deserticola. Arch Pharm Res 31, 1108-1114, doi:10.1007/s12272-001-1276-4 (2008).

34 Lin, A. et al. Two new 5-hydroxy-2-pyrone derivatives isolated from a marinederived fungus Aspergillus flavus. J Antibiot (Tokyo) 61, 245-249, doi:10.1038/ja.2008.36 (2008).

$35 \mathrm{Du}, \mathrm{L} .$, Zhu, T., Fang, Y., Gu, Q. \& Zhu, W. Unusual C25 steroid isomers with bicyclo[4.4.1]A/B rings from a volcano ash-derived fungus Penicillium citrinum. $J$ Nat Prod 71, 1343-1351, doi:10.1021/np8000442 (2008).

36 Tanaka, S., Shaikh, I. M., Chiocca, E. A. \& Saeki, Y. The Gs-linked receptor GPR3 inhibits the proliferation of cerebellar granule cells during postnatal development. PLoS One 4, e5922, doi:10.1371/journal.pone.0005922 (2009).

37 Huang, Y. et al. Loss of GPR3 reduces the amyloid plaque burden and improves memory in Alzheimer's disease mouse models. Sci Transl Med 7, 309ra164, doi:10.1126/scitranslmed.aab3492 (2015).

38 Ruiz-Medina, J., Ledent, C. \& Valverde, O. GPR3 orphan receptor is involved in neuropathic pain after peripheral nerve injury and regulates morphine-induced antinociception. Neuropharmacology 61, 43-50, doi:10.1016/j.neuropharm.2011.02.014 (2011).

39 Tourino, C. et al. The orphan receptor GPR3 modulates the early phases of cocaine reinforcement. British journal of pharmacology 167, 892-904, doi:10.1111/j.1476-5381.2012.02043.x (2012).

40 Godlewski, G. et al. Mice lacking GPR3 receptors display late-onset obese phenotype due to impaired thermogenic function in brown adipose tissue. Sci Rep $\mathbf{5}$, 14953, doi:10.1038/srep14953 (2015).

41 Richard, F. J. Regulation of meiotic maturation. J Anim Sci 85, E4-6, doi:10.2527/jas.2006-475 (2007).

42 Mehlmann, L. M. et al. The Gs-linked receptor GPR3 maintains meiotic arrest in mammalian oocytes. Science 306, 1947-1950, doi:10.1126/science.1103974 (2004). 43 Norris, R. P. et al. A G(s)-linked receptor maintains meiotic arrest in mouse oocytes, but luteinizing hormone does not cause meiotic resumption by terminating receptor-G(s) signaling. Dev Biol 310, 240-249, doi:10.1016/j.ydbio.2007.07.017 (2007). 44 Deng, J., Lang, S., Wylie, C. \& Hammes, S. R. The Xenopus laevis isoform of G protein-coupled receptor 3 (GPR3) is a constitutively active cell surface receptor that 
participates in maintaining meiotic arrest in X. laevis oocytes. Mol Endocrinol 22, 18531865, doi:10.1210/me.2008-0124 (2008).

45 Yang, C. R. et al. The G protein coupled receptor 3 is involved in cAMP and cGMP signaling and maintenance of meiotic arrest in porcine oocytes. PLoS One 7, e38807, doi:10.1371/journal.pone.0038807 (2012).

46 Ledent, C. et al. Premature ovarian aging in mice deficient for Gpr3. Proc Natl Acad Sci U S A 102, 8922-8926, doi:10.1073/pnas.0503840102 (2005).

47 Cai, D. et al. Neuronal cyclic AMP controls the developmental loss in ability of axons to regenerate. J Neurosci 21, 4731-4739 (2001).

48 Alexander, J. J., Anderson, A. J., Barnum, S. R., Stevens, B. \& Tenner, A. J. The complement cascade: Yin-Yang in neuroinflammation--neuro-protection and degeneration. J Neurochem 107, 1169-1187, doi:10.1111/j.1471-4159.2008.05668.x (2008).

49 Benoit, M. E. et al. C1q-induced LRP1B and GPR6 proteins expressed early in Alzheimer disease mouse models, are essential for the $\mathrm{C} 1 \mathrm{q}$-mediated protection against amyloid-beta neurotoxicity. J Biol Chem 288, 654-665, doi:10.1074/jbc.M112.400168 (2013).

50 Oeckl, P., Hengerer, B. \& Ferger, B. G-protein coupled receptor 6 deficiency alters striatal dopamine and cAMP concentrations and reduces dyskinesia in a mouse model of Parkinson's disease. Exp Neurol 257, 1-9, doi:10.1016/j.expneurol.2014.04.010 (2014).

51 Lobo, M. K., Cui, Y., Ostlund, S. B., Balleine, B. W. \& Yang, X. W. Genetic control of instrumental conditioning by striatopallidal neuron-specific S1P receptor Gpr6. Nat Neurosci 10, 1395-1397, doi:10.1038/nn1987 (2007).

52 Miyagi, T., Tanaka, S., Hide, I., Shirafuji, T. \& Sakai, N. The Subcellular Dynamics of the Gs-Linked Receptor GPR3 Contribute to the Local Activation of PKA in Cerebellar Granular Neurons. PLoS One 11, e0147466, doi:10.1371/journal.pone.0147466 (2016).

53 Bjursell, M. et al. G protein-coupled receptor 12 deficiency results in dyslipidemia and obesity in mice. Biochem Biophys Res Commun 348, 359-366, doi:10.1016/j.bbrc.2006.07.090 (2006).

54 Lu, X., Zhang, N., Meng, B., Dong, S. \& Hu, Y. Involvement of GPR12 in the regulation of cell proliferation and survival. Mol Cell Biochem 366, 101-110, doi:10.1007/s11010-012-1287-x (2012).

55 Beil, M. et al. Sphingosylphosphorylcholine regulates keratin network architecture and visco-elastic properties of human cancer cells. Nat Cell Biol 5, 803-811, doi:10.1038/ncb1037 (2003).

56 Park, M. K. et al. Novel effects of FTY720 on perinuclear reorganization of keratin network induced by sphingosylphosphorylcholine: Involvement of protein phosphatase 2A and G-protein-coupled receptor-12. Eur J Pharmacol 775, 86-95, doi:10.1016/j.ejphar.2016.02.024 (2016).

57 Eggerickx, D. et al. Molecular cloning of an orphan G-protein-coupled receptor that constitutively activates adenylate cyclase. The Biochemical journal 309 ( Pt 3), 837843 (1995). 
58 Prasad, B. M., Hollins, B. \& Lambert, N. A. Methods to detect cell surface expression and constitutive activity of GPR6. Methods Enzymol 484, 179-195, doi:10.1016/B978-0-12-381298-8.00010-1 (2010).

59 Komatsu, H. Novel Therapeutic GPCRs for Psychiatric Disorders. Int J Mol Sci 16, 14109-14121, doi:10.3390/ijms160614109 (2015).

60 Kostenis, E. Novel clusters of receptors for sphingosine-1-phosphate, sphingosylphosphorylcholine, and (lyso)-phosphatidic acid: new receptors for "old" ligands. Journal of cellular biochemistry 92, 923-936, doi:10.1002/jcb.20092 (2004). 61 Yin, H. et al. Lipid G protein-coupled receptor ligand identification using betaarrestin PathHunter assay. The Journal of biological chemistry 284, 12328-12338, doi:10.1074/jbc.M806516200 (2009).

62 Lee, D. K., George, S. R., Evans, J. F., Lynch, K. R. \& O'Dowd, B. F. Orphan G protein-coupled receptors in the CNS. Curr Opin Pharmacol 1, 31-39 (2001). 63 Pertwee, R. G. \& Ross, R. A. Cannabinoid receptors and their ligands. Prostaglandins Leukot Essent Fatty Acids 66, 101-121, doi:10.1054/plef.2001.0341 (2002).

64 Bassoni, D. L., Raab, W. J., Achacoso, P. L., Loh, C. Y. \& Wehrman, T. S. Measurements of beta-arrestin recruitment to activated seven transmembrane receptors using enzyme complementation. Methods in molecular biology 897, 181-203, doi:10.1007/978-1-61779-909-9_9 (2012).

65 Porter, A. C. et al. Characterization of a novel endocannabinoid, virodhamine, with antagonist activity at the CB1 receptor. The Journal of pharmacology and experimental therapeutics 301, 1020-1024 (2002).

66 Hanus, L. et al. 2-arachidonyl glyceryl ether, an endogenous agonist of the cannabinoid CB1 receptor. Proceedings of the National Academy of Sciences of the United States of America 98, 3662-3665, doi:10.1073/pnas.061029898 (2001).

67 Fezza, F. et al. Noladin ether, a putative novel endocannabinoid: inactivation mechanisms and a sensitive method for its quantification in rat tissues. FEBS letters $\mathbf{5 1 3}$, 294-298 (2002).

68 Izzo, A. A., Borrelli, F., Capasso, R., Di Marzo, V. \& Mechoulam, R. Nonpsychotropic plant cannabinoids: new therapeutic opportunities from an ancient herb. Trends in pharmacological sciences 30, 515-527, doi:10.1016/j.tips.2009.07.006 (2009). 69 Zuardi, A. W. Cannabidiol: from an inactive cannabinoid to a drug with wide spectrum of action. Rev Bras Psiquiatr 30, 271-280 (2008).

70 Pertwee, R. The pharmacology and therapeutic potential of cannabidiol Di Marzo, V.,Ed., Cannabinoids, 32-83 (2004).

71 Pertwee, R. G. The diverse CB1 and CB2 receptor pharmacology of three plant cannabinoids: delta9-tetrahydrocannabinol, cannabidiol and delta9tetrahydrocannabivarin. British journal of pharmacology 153, 199-215, doi:10.1038/sj.bjp.0707442 (2008).

72 Laprairie, R. B., Bagher, A. M., Kelly, M. E. \& Denovan-Wright, E. M. Cannabidiol is a negative allosteric modulator of the cannabinoid CB1 receptor. $\mathrm{Br} J$ Pharmacol 172, 4790-4805, doi:10.1111/bph.13250 (2015).

73 Russo, E. B., Burnett, A., Hall, B. \& Parker, K. K. Agonistic properties of cannabidiol at 5-HT1 a receptors. Neurochem Res 30, 1037-1043, doi:10.1007/s11064005-6978-1 (2005). 
74 Ryberg, E. et al. The orphan receptor GPR55 is a novel cannabinoid receptor. $\mathrm{Br}$ J Pharmacol 152, 1092-1101, doi:10.1038/sj.bjp.0707460 (2007).

75 Kathmann, M., Flau, K., Redmer, A., Trankle, C. \& Schlicker, E. Cannabidiol is an allosteric modulator at mu- and delta-opioid receptors. Naunyn Schmiedebergs Arch Pharmacol 372, 354-361, doi:10.1007/s00210-006-0033-x (2006).

76 Garcia-Arencibia, M. et al. Evaluation of the neuroprotective effect of cannabinoids in a rat model of Parkinson's disease: importance of antioxidant and cannabinoid receptor-independent properties. Brain Res 1134, 162-170, doi:10.1016/j.brainres.2006.11.063 (2007).

77 Lastres-Becker, I., Molina-Holgado, F., Ramos, J. A., Mechoulam, R. \& Fernandez-Ruiz, J. Cannabinoids provide neuroprotection against 6-hydroxydopamine toxicity in vivo and in vitro: relevance to Parkinson's disease. Neurobiol Dis 19, 96-107, doi:10.1016/j.nbd.2004.11.009 (2005).

78 Campos, A. C., Fogaca, M. V., Sonego, A. B. \& Guimaraes, F. S. Cannabidiol, neuroprotection and neuropsychiatric disorders. Pharmacological research : the official journal of the Italian Pharmacological Society 112, 119-127, doi:10.1016/j.phrs.2016.01.033 (2016).

79 Watt, G. \& Karl, T. In vivo Evidence for Therapeutic Properties of Cannabidiol (CBD) for Alzheimer's Disease. Front Pharmacol 8, 20, doi:10.3389/fphar.2017.00020 (2017).

80 Cheng, D., Low, J. K., Logge, W., Garner, B. \& Karl, T. Chronic cannabidiol treatment improves social and object recognition in double transgenic APPswe/PS1E9 mice. Psychopharmacology (Berl) 231, 3009-3017, doi:10.1007/s00213-014-3478-5 (2014).

81 McAllister, S. D., Soroceanu, L. \& Desprez, P. Y. The Antitumor Activity of Plant-Derived Non-Psychoactive Cannabinoids. J Neuroimmune Pharmacol 10, 255-267, doi:10.1007/s11481-015-9608-y (2015).

82 Celik, O., Celik, N., Gungor, S., Haberal, E. T. \& Aydin, S. Selective Regulation of Oocyte Meiotic Events Enhances Progress in Fertility Preservation Methods. Biochem Insights 8, 11-21, doi:10.4137/BCI.S28596 (2015).

83 Reich, R. et al. In vitro effects of cannabinoids on follicular function in the rat. Biol Reprod 27, 223-231 (1982).

84 Izzo, A. A., Borrelli, F., Capasso, R., Di Marzo, V. \& Mechoulam, R. Nonpsychotropic plant cannabinoids: new therapeutic opportunities from an ancient herb. Trends Pharmacol Sci 30, 515-527, doi:10.1016/j.tips.2009.07.006 (2009).

85 Campos, A. C. \& Guimaraes, F. S. Involvement of 5HT1A receptors in the anxiolytic-like effects of cannabidiol injected into the dorsolateral periaqueductal gray of rats. Psychopharmacology 199, 223-230, doi:10.1007/s00213-008-1168-x (2008).

86 Yang, K. H. et al. The nonpsychoactive cannabinoid cannabidiol inhibits 5hydroxytryptamine3A receptor-mediated currents in Xenopus laevis oocytes. $J$ Pharmacol Exp Ther 333, 547-554, doi:10.1124/jpet.109.162594 (2010).

87 Rong, C. et al. Cannabidiol in medical marijuana: Research vistas and potential opportunities. Pharmacol Res 121, 213-218, doi:10.1016/j.phrs.2017.05.005 (2017). 


\title{
CURRICULUM VITAE
}

\author{
Alyssa S. Laun \\ Email: aslaun01@louisville.edu
}

Department of Pharmacology and Toxicology

500 S. Preston St.

519 School Way

Bldg. A Room 1305

Louisville, KY, 40214

Louisville, KY, 40292

(502)641-6137

(502)852-2404

Education:

University of Louisville

Louisville, KY

Degree: Doctor of Philosophy

2015-Present

Major: Pharmacology and Toxicology

Overall GPA: 3.75

University of Louisville

Louisville, $\mathrm{KY}$

Degree: Bachelor of science

2008-2014

Major: Psychology BS, Biology BS- cellular/physiology

Minor: Chemistry- track 1

Overall GPA: 3.1

Publications:

[1] A. Aloway, A. Kumar, A.S. Laun, Z.H. Song, Cannabinoid Regulation of Intraocular Pressure: Human and Animal Studies, Cellular and Molecular Targets, in: V. Preedy

(Ed.) Handbook of Cannabis and Related Pathologies, Elsevier2017.

[2] Z.H. Song, A.S. Laun, J. Cai, Mass Spectrometry Analysis of Human CB2

Cannabinoid Receptor and Its Associated Proteins, Methods Enzymol, 593 (2017) 371386.

[3] A.S. Laun, Z.H. Song, GPR3 and GPR6, novel molecular targets for cannabidiol, Biochem Biophys Res Commun, 490 (2017) 17-21.

[4] K.J. Brown, A.S. Laun, Z.H. Song, Cannabidiol, a novel inverse agonist for GPR12, Biochem Biophys Res Commun, 493 (2017) 451-454.

Abstracts and Conference Presentations:

[1] A.S. Laun, P. Kumar, Z.H. Song, Cannabigerol Modulates the Efficacy of

Cannabinoids on CB2 Receptor, UofL NCI R25 Cancer Education ProgramLouisville, KY, USA, 2014. 
[2] A.S. Laun, P. Kumar, Z.H. Song, Cannabigerol Modulates the Efficacy of Anandamide on the CB2 Cannabinoid Receptor, 25th Annual Symposium of the International Cannabinoid Research SocietyWolfville, Nova Scotia, 2015, pp. 60. [3] A.S. Laun, Z.H. Song, The Modulatory Effects of Pregnenolone On CB1 and CB2 Cannabinoid Receptors, Research! LouisvilleLouisville, KY, USA, 2016.

[4] K.J. Brown, A.S. Laun, Z.H. Song, The Effect of Various Classes of Cannabinoids on GPR12, UofL NCI R25 Cancer Education ProgramUniversity of Louisville, 2017.

[5] A.S. Laun, P.H. Reggio, Z.H. Song, Cannabidiol, a Novel Biased Inverse Agonist for GPR3, 27th Annual Symposium of the International Cannabinoid Research

SocietyMontreal, QC, Canada, 2017, pp. 50.

[6] Z.H. Song, A.S. Laun, GPR3 AND GPR6, NOVEL MOLECULAR TARGETS FOR CANNABIDIOL, 27th Annual Symposium on the Cannabinoids, International Cannabinoid Research Society, Montreal, Quebec, Canada, 2017, pp. P3-9.

[7] J. Mnpotra, A.S. Laun, Z.H. Song, A. Griffith, H. Seltzman, D.P. Hurst, P.H. Reggio, Can a Ligand Switch CB1 Signaling From Inhibitory (Gi) to Stimulatory (Gs) G Protein?, 27th Annual Symposium of the International Cannabinoid Research SocietyMontreal, QC, Canada, 2017, pp. P1-28.

[8] I. Isawi, P. Morales, A.S. Laun, D.P. Hurst, Z.H. Song, P.H. Reggio, Structural Relationship of the Class A Orphan GPCR, GPR6 With the Cannabinoid CB1 and CB2 Receptors, 27th Annual Symposium of the International Cannabinoid Research SocietyMontreal, QC, Canada, 2017, pp. P1-29.

[9] P. Morales, A.S. Laun, D.P. Hurst, Z.H. Song, P.H. Reggio, Functional Selectivity of CBD in the Orphan Receptor GPR3: A Structural Focus, 27th Annual Symposium of the International Cannabinoid Research SocietyMontreal, QC, Canada, 2017, pp. P3-12.

Research Presentations:

The role of the orphan GPR3 receptor in Alzheimer's disease

March 2015

Department of Pharmacology and Toxicology research seminar

Travel Awards:

ICRS Travel award

Graduate student travel award

Summer 2015, 2017

Honors/awards

NCI R25 Cancer Education Program stipend

Summer 2015

Undergraduate Research Experience

Cancer education program

Louisville, KY

Undergraduate researcher

Summer 2014, 2015

- Conduct research under guidance of a mentor

- Present poster and abstract

- Attend seminars on research conduct and lab safety, speed networking workshops, as well as cancer colloquia from outside speakers.

- Present a seminar to first- time participants in the program on my research from the previous summer. 
Dr. Woodruff- Borden's Family Anxiety lab

Research assistant

$2012-2013$

- Data entry from patient collected surveys into excel spreadsheet

- Familiarity with surveys and questionnaires relevant to anxiety and depression

- Organization of patient surveys into parent and child packets

- Interview coding from a recording into a word document for use by the lab

Work Experience:

Scribe America

Medical Scribe

Jan 2015- Apr 2015

University of Louisville

Temporary laboratory assistant

Aug 2014- Jun 2015

UPS

Package Handler

2011-2014

Rite Aid Pharmacy

Nationally Certified Pharmacy Technician

2009-2011

Collegebook Warehouse

Louisville, KY

Sales associate

7/2009-9/2009 